\title{
Asset pricing with liquidity risk ${ }^{\text {th }}$
}

\author{
Viral V. Acharya ${ }^{\mathrm{a}, \mathrm{b}}$, Lasse Heje Pedersen ${ }^{\mathrm{b}, \mathrm{c}, \mathrm{d}, *}$ \\ ${ }^{a}$ London Business School, Regent's Park, London, NW1 4SA, UK \\ ${ }^{\mathrm{b}}$ Center for Economic Policy Research, UK \\ ${ }^{\mathrm{c}}$ Stern School of Business, New York University, 44 West Fourth Street, Suite 9-190, New York 10012, USA \\ ${ }^{\mathrm{d}}$ National Bureau of Economic Research, USA
}

Received 6 January 2003; received in revised form 4 May 2004; accepted 11 June 2004

Available online 1 April 2005

\begin{abstract}
This paper solves explicitly a simple equilibrium model with liquidity risk. In our liquidityadjusted capital asset pricing model, a security's required return depends on its expected liquidity as well as on the covariances of its own return and liquidity with the market return and liquidity. In addition, a persistent negative shock to a security's liquidity results in low contemporaneous returns and high predicted future returns. The model provides a unified framework for understanding the various channels through which liquidity risk may affect asset prices. Our empirical results shed light on the total and relative economic significance of these channels and provide evidence of flight to liquidity.
\end{abstract}

(C) 2005 Elsevier B.V. All rights reserved.

\section{JEL classification: G0; G1; G12}

Keywords: Liquidity risk; Liquidity-adjusted CAPM; Flight to liquidity; Frictions; Transaction costs

\footnotetext{
${ }^{2}$ We are grateful for conversations with Andrew Ang, Joseph Chen, Sergei Davydenko, Francisco Gomes, Joel Hasbrouck, Andrew Jackson, Tim Johnson, Martin Lettau, Anthony Lynch, Stefan Nagel, Lubos Pastor, Tano Santos, Dimitri Vayanos, Luis Viceira, Jeff Wurgler, and seminar participants at London Business School, London School of Economics, New York University, the National Bureau of Economic Research (NBER) Summer Institute 2002, the Five Star Conference 2002, the Western Finance Association Meetings 2003, and the Texas Finance Festival 2004. We are especially indebted to Yakov Amihud and to an anonymous referee for help and many valuable suggestions.

*Corresponding author. Stern School of Business, New York University, 44 West Fourth Street, Suite 9-190, New York 10012, USA. Fax: + 12129954233.

E-mail address: lpederse@stern.nyu.edu (L.H. Pedersen).
} 


\section{Introduction}

Liquidity is risky and has commonalty: it varies over time both for individual stocks and for the market as a whole (Chordia et al., 2000; Hasbrouck and Seppi, 2001; Huberman and Halka, 1999). Liquidity risk is often noted in the financial press. For instance:

The possibility that liquidity might disappear from a market, and so not be available when it is needed, is a big source of risk to an investor.

- The Economist, September 23, 1999

...there is also broad belief among users of financial liquidity-traders, investors and central bankers - that the principal challenge is not the average level of financial liquidity... but its variability and uncertainty....

-Persaud (2003)

This paper presents a simple theoretical model that helps explain how asset prices are affected by liquidity risk and commonality in liquidity. The model provides a unified theoretical framework that can explain the empirical findings that return sensitivity to market liquidity is priced (Pastor and Stambaugh, 2003), that average liquidity is priced (Amihud and Mendelson, 1986), and that liquidity comoves with returns and predicts future returns (Amihud, 2002; Chordia et al., 2001a; Jones, 2001; Bekaert et al., 2003).

In our model, risk-averse agents in an overlapping generations economy trade securities whose liquidity varies randomly over time. We solve the model explicitly and derive a liquidity-adjusted capital asset pricing model (CAPM). Our model of liquidity risk complements the existing theoretical literature on asset pricing with constant trading frictions (see, for instance, Amihud and Mendelson, 1986; Constantinides, 1986; Vayanos, 1998; Vayanos and Vila, 1999; Duffie et al., 2000, 2003; Huang, 2003; Gârleanu and Pedersen, 2004). In the liquidity-adjusted CAPM, the expected return of a security is increasing in its expected illiquidity and its "net beta," which is proportional to the covariance of its return, $r^{i}$, net of its exogenous ${ }^{1}$ illiquidity costs, $c^{i}$, with the market portfolio's net return, $r^{M}-c^{M}$. The net beta can be decomposed into the standard market beta and three betas representing different forms of liquidity risk. These liquidity risks are associated with: (i) commonality in liquidity with the market liquidity, $\operatorname{cov}\left(c^{i}, c^{M}\right)$; (ii) return sensitivity to market liquidity, $\operatorname{cov}\left(r^{i}, c^{M}\right)$; and, (iii) liquidity sensitivity to market returns, $\operatorname{cov}\left(c^{i}, r^{M}\right)$.

We explore the cross-sectional predictions of the model using NYSE and AMEX stocks over the period 1963 to 1999 . We use the illiquidity measure of Amihud (2002) to proxy for $c^{i}$. We find that the liquidity-adjusted CAPM fares better than the standard CAPM in terms of $R^{2}$ for cross-sectional returns and $p$-values in specification tests, even though both models employ exactly one degree of freedom.

\footnotetext{
${ }^{1}$ While research on endogenous time-variation in illiquidity is sparse, Eisfeldt (2004) presents a model in which real-sector liquidity fluctuates with productivity, Brunnermeier and Pedersen (2004b) show how predatory trading can lead to illiquidity when liquidity is most needed, and Brunnermeier and Pedersen (2004a) show how market liquidity varies with dealers' "funding liquidity."
} 
The model has a good fit for portfolios sorted on liquidity, liquidity variation, and size, but the model cannot explain the cross-sectional returns associated with the book-to-market effect.

An interesting result that emerges from our empirical exercises based on Amihud's illiquidity measure is that illiquid securities also have high liquidity risk, consistent with "flight to liquidity" in times of down markets or generally illiquid markets. In particular, a security that has high average illiquidity, $c^{i}$, also tends to have high commonality in liquidity with the market liquidity, high return sensitivity to market liquidity, and high liquidity sensitivity to market returns.

While this collinearity is itself interesting, it also complicates the task of distinguishing statistically the relative return impacts of liquidity, liquidity risk, and market risk. There is, however, some evidence that the total effect of the three liquidity risks matters over and above market risk and the level of liquidity.

It is interesting to consider the total and relative economic significance of liquidity level and each of the three liquidity risks by evaluating their contribution to crosssectional return differences. It is difficult, however, to accurately distinguish the relative economic effects because of the inherent collinearity in the data. One of the benefits of having an economic model is that it provides a restrictive structure under which the identification problem is alleviated. Under the model's restrictions, liquidity risk contributes on average about $1.1 \%$ annually to the difference in risk premium between stocks with high expected illiquidity and low expected illiquidity. We decompose the effect of liquidity risk into the contribution from each of the three kinds of risk, recognizing that these estimates are subject to error and rely on the validity of the model:

- First, we estimate that the return premium due to commonality in liquidity, $\operatorname{cov}\left(c^{i}, c^{M}\right)$, is $0.08 \%$. Hence, while the model shows that investors require a return premium for a security that is illiquid when the market as a whole is illiquid, this effect appears to be small. The commonality in liquidity has been documented by Chordia et al. (2000), Huberman and Halka (1999), and Hasbrouck and Seppi (2001), but these papers do not study the implications for required returns.

- Second, we estimate that the return premium due to $\operatorname{cov}\left(r^{i}, c^{M}\right)$ is $0.16 \%$. This model-implied premium stems from the preference of investors for securities with high returns when the market is illiquid. Pastor and Stambaugh (2003) find empirical support for this effect using monthly data over 34 years with a measure of liquidity that they construct based on the return reversals induced by order flow.

- Third, we estimate that the return premium due to $\operatorname{cov}\left(c^{i}, r^{M}\right)$ is $0.82 \%$. Intuitively, investors are willing to pay a premium for a security that is liquid when the market return is low. We note that $\operatorname{cov}\left(c^{i}, r^{M}\right)$ appears to be the most important source of liquidity risk although it has not previously been considered in the academic literature. However, it is reflected in industry practices such as legal disclaimers for certain asset management firms; e.g., 
Risks of investing in smaller companies include... the potential difficulty of selling these stocks during market downturns (illiquidity).

—Legal Disclaimer, Investec Asset Management, 2004. ${ }^{2}$

The return premium due to the level of liquidity is calibrated based on the average turnover to be $3.5 \%$, thus the combined effect of the differences in liquidity risks and differences in the level of liquidity is estimated to be $4.6 \%$ per year. These estimates of the relative importance of liquidity level and the liquidity risks depend on the model-implied restrictions of a single risk premium and a level effect consistent with the turnover. If we depart from the model restrictions and estimate each liquidity risk premium as a free parameter then the economic effect of liquidity risk appears to be larger, but the unrestricted premia are estimated with little precision. Pastor and Stambaugh (2003) find a large $(7.5 \%)$ effect of liquidity risk $\left(\operatorname{cov}\left(r^{i}, c^{M}\right)\right)$ using an unrestricted liquidity risk premium and without controlling for the level of liquidity.

Finally, the model also shows that since liquidity is persistent, ${ }^{3}$ liquidity predicts future returns and liquidity co-moves with contemporaneous returns. This is because a positive shock to illiquidity predicts high future illiquidity, which raises the required return and lowers contemporaneous prices. This may help explain the empirical findings of Amihud et al. (1990), Amihud (2002), Chordia et al. (2001a), Jones (2001), and Pastor and Stambaugh (2003) in the U.S. stock market, and of Bekaert et al. (2003) in emerging markets.

In summary, we offer a simple theoretical framework that illustrates several channels through which liquidity risk can affect asset prices. The model is a useful first step in understanding how a number of recent empirical findings fit together. Finally, our empirical analysis suggests that the effects of liquidity level and liquidity risk are separate, although the analysis is made difficult by collinearity, and that one channel for liquidity risk that has not been treated in the prior literature, namely $\operatorname{cov}\left(c^{i}, r^{M}\right)$, may be of empirical importance.

The paper is organized as follows. Section 2 describes the economy. Section 3 derives the liquidity-adjusted capital asset pricing model and outlines how liquidity predicts and co-moves with returns. Section 4 contains an empirical analysis. Section 5 concludes. Proofs are in the Appendix.

\section{Assumptions}

The model assumes a simple overlapping generations economy in which a new generation of agents is born at any time $t \in\{\ldots,-2,-1,0,1,2, \ldots\}$ (Samuelson, 1958). Generation $t$ consists of $N$ agents, indexed by $n$, who live for two periods, $t$ and $t+1$. Agent $n$ of generation $t$ has an endowment at time $t$ and no other sources of income, trades in periods $t$ and $t+1$, and derives utility from consumption at time $t+1$. He has constant absolute risk aversion $A^{n}$ so that his preferences are

\footnotetext{
${ }^{2}$ Source: http://www2.investecfunds.com/US/LegalDisclaimer/Index.cfm

${ }^{3}$ Amihud (2002), Chordia et al. (2000, 2001a,b), Hasbrouck and Seppi (2001), Huberman and Halka (1999), Jones (2001), and Pastor and Stambaugh (2003).
} 
represented by the expected utility function $-E_{t} \exp \left(-A^{n} x_{t+1}\right)$, where $x_{t+1}$ is his consumption at time $t+1$.

There are $I$ securities indexed by $i=1, \ldots, I$ with a total of $S^{i}$ shares of security $i$. At time $t$, security $i$ pays a dividend of $D_{t}^{i}$, has an ex-dividend share price of $P_{t}^{i}$, and has an illiquidity cost of $C_{t}^{i}$, where $D_{t}^{i}$ and $C_{t}^{i}$ are random variables. All random variables are defined on a probability space $(\Omega, \mathscr{F}, \mathscr{P})$, and all random variables indexed by $t$ are measurable with respect to the filtration $\left\{\mathscr{F}_{t}\right\}$, representing the information commonly available to investors. The illiquidity cost, $C_{t}^{i}$, is modeled simply as the per-share cost of selling security $i$. Hence, agents can buy at $P_{t}^{i}$ but must sell at $P_{t}^{i}-C_{t}^{i}$. Short-selling is not allowed.

Uncertainty about the illiquidity cost is what generates the liquidity risk in this model. Specifically, we assume that $D_{t}^{i}$ and $C_{t}^{i}$ are autoregressive processes of order one, that is:

$$
\begin{aligned}
& D_{t}=\bar{D}+\rho^{D}\left(D_{t-1}-\bar{D}\right)+\varepsilon_{t} \\
& C_{t}=\bar{C}+\rho^{C}\left(C_{t-1}-\bar{C}\right)+\eta_{t},
\end{aligned}
$$

where $^{4} \bar{D}, \bar{C} \in \mathbb{R}_{+}^{I}$ are positive real vectors, $\rho^{D}, \rho^{C} \in[0,1]$, and $\left(\varepsilon_{t}, \eta_{t}\right)$ is an independent identically distributed normal process with mean $E\left(\varepsilon_{t}\right)=E\left(\eta_{t}\right)=0$ and variance-covariance matrices $\operatorname{var}\left(\varepsilon_{t}\right)=\Sigma^{D}, \operatorname{var}\left(\eta_{t}\right)=\Sigma^{C}$, and $E\left(\varepsilon_{t} \eta_{t}^{\top}\right)=\Sigma^{C D}$.

We assume that agents can borrow and lend at a risk-free real return of $r^{f}>1$, which is exogenous. This can be interpreted as an inelastic bond market, or a generally available production technology that turns a unit of consumption at time $t$ into $r^{f}$ units of consumption at time $t+1$.

The assumptions with respect to agents, preferences, and dividends are strong. These assumptions are made for tractability, and, as we shall see, they imply natural closed-form results for prices and expected returns. The main result (Proposition 1) applies more generally, however. It holds for an arbitrary increasing and concave utility function defined on $(-\infty, \infty)$ as long as conditional expected net returns are normal, ${ }^{5}$ and also for an arbitrary return distribution and quadratic utility. Furthermore, it can be viewed as a result of near-rational behavior, for instance, by using a Taylor expansion of the utility function (see, for example, Huang and Litzenberger, 1988; Markowitz, 2000; Cochrane, 2001). Our assumptions also allow us to study return predictability caused by illiquidity (Proposition 2) and the comovements of returns and illiquidity (Proposition 3), producing insights that also seem robust to the specification.

Perhaps the strongest assumption is that investors need to sell all their securities after one period (when they die). In a more general setting with endogenous holding periods, deriving a general equilibrium with time-varying liquidity is an onerous task. While our model is mostly suggestive, it is helpful since it provides guidelines

\footnotetext{
${ }^{4}$ For notational convenience, we assume that all securities have the same autocorrelation of dividends and liquidity $\left(\rho^{D}\right.$ and $\left.\rho^{C}\right)$ although our results apply more generally.

${ }^{5}$ The normal returns assumption is an assumption about endogenous variables that is used in standard CAPM analysis (for instance, Huang and Litzenberger, 1988). This assumption is satisfied in the equilibrium of the model of this paper.
} 
concerning the first-order effect of liquidity risk, showing which risks are priced. The assumption of overlapping generations can capture investors' life-cycle motives for trade (as in Vayanos, 1998; Constantinides et al., 2002), or can be viewed as a way of capturing short investment horizons (as in De Long et al., 1990) and the large turnover observed empirically in many markets.

It should also be noted that a narrow interpretation of the illiquidity $\operatorname{cost}, C_{t}^{i}$, is that it represents transactions costs such as broker fees and bid-ask spread, in line with the literature on exogenous transactions costs. More broadly, however, the illiquidity cost could represent other real costs, for instance, those arising from delay and search associated with trade execution as in Duffie et al. (2000, 2002, 2003). The novelty in our model arises from the fact that we allow this cost to be time-varying.

\section{Liquidity-adjusted capital asset pricing model}

This section derives a liquidity-adjusted version of the capital asset pricing model (CAPM) and studies its asset pricing implications.

We are interested in how an asset's expected (gross) return,

$$
r_{t}^{i}=\frac{D_{t}^{i}+P_{t}^{i}}{P_{t-1}^{i}},
$$

depends on its relative illiquidity cost,

$$
c_{t}^{i}=\frac{C_{t}^{i}}{P_{t-1}^{i}},
$$

on the market return,

$$
r_{t}^{M}=\frac{\sum_{i} S^{i}\left(D_{t}^{i}+P_{t}^{i}\right)}{\sum_{i} S^{i} P_{t-1}^{i}},
$$

and on the relative market illiquidity,

$$
c_{t}^{M}=\frac{\sum_{i} S^{i} C_{t}^{i}}{\sum_{i} S^{i} P_{t-1}^{i}} .
$$

In a competitive equilibrium of the model (henceforth referred to simply as equilibrium), agents choose consumption and portfolios so as to maximize their expected utility taking prices as given, and prices are determined such that markets clear.

To determine equilibrium prices, consider first an economy with the same agents in which asset $i$ has a dividend of $D_{t}^{i}-C_{t}^{i}$ and no illiquidity cost. In this imagined economy, standard results imply that the CAPM holds (Markowitz, 1952; Sharpe, 1964; Lintner, 1965; Mossin, 1966). We claim that the equilibrium prices in the original economy with frictions are the same as those of the imagined economy. This follows from two facts: (i) the net return on a long position is the same in both economies; and, (ii) all investors in the imagined economy hold a long position in the 
market portfolio, and a (long or short) position in the risk-free asset. Hence, an investor's equilibrium return in the frictionless economy is feasible in the original economy, and is also optimal, given the more limited investment opportunities due to the short-selling constraints. (This argument applies more generally since positive transactions costs imply that a short position has a worse payoff than minus the payoff of a long position. We impose the short-sale constraint because $C$ can be negative in a setting with normal distributions.)

These arguments show that the CAPM in the imagined frictionless economy translates into a CAPM in net returns for the original economy with illiquidity costs. Rewriting the one-beta CAPM in net returns in terms of gross returns, we get a liquidity-adjusted CAPM for gross returns. This is the main testable ${ }^{6}$ implication of this paper:

Proposition 1. In the unique linear equilibrium, the conditional expected net return of security $i$ is

$$
E_{t}\left(r_{t+1}^{i}-c_{t+1}^{i}\right)=r^{f}+\lambda_{t} \frac{\operatorname{cov}_{t}\left(r_{t+1}^{i}-c_{t+1}^{i}, r_{t+1}^{M}-c_{t+1}^{M}\right)}{\operatorname{var}_{t}\left(r_{t+1}^{M}-c_{t+1}^{M}\right)},
$$

where $\lambda_{t}=E_{t}\left(r_{t+1}^{M}-c_{t+1}^{M}-r^{f}\right)$ is the risk premium. Equivalently, the conditional expected gross return is

$$
\begin{aligned}
E_{t}\left(r_{t+1}^{i}\right)= & r^{f}+E_{t}\left(c_{t+1}^{i}\right)+\lambda_{t} \frac{\operatorname{cov}_{t}\left(r_{t+1}^{i}, r_{t+1}^{M}\right)}{\operatorname{var}_{t}\left(r_{t+1}^{M}-c_{t+1}^{M}\right)}+\lambda_{t} \frac{\operatorname{cov}_{t}\left(c_{t+1}^{i}, c_{t+1}^{M}\right)}{\operatorname{var}_{t}\left(r_{t+1}^{M}-c_{t+1}^{M}\right)} \\
& -\lambda_{t} \frac{\operatorname{cov}_{t}\left(r_{t+1}^{i}, c_{t+1}^{M}\right)}{\operatorname{var}_{t}\left(r_{t+1}^{M}-c_{t+1}^{M}\right)}-\lambda_{t} \frac{\operatorname{cov}_{t}\left(c_{t+1}^{i}, r_{t+1}^{M}\right)}{\operatorname{var}_{t}\left(r_{t+1}^{M}-c_{t+1}^{M}\right)} .
\end{aligned}
$$

Eq. (8) is simple and natural. It states that the required excess return is the expected relative illiquidity cost, $E_{t}\left(c_{t+1}^{i}\right)$, as found theoretically and empirically ${ }^{7}$ by Amihud and Mendelson (1986)), plus four betas (or covariances) times the risk premium. These four betas depend on the asset's payoff and liquidity risks. As in the standard CAPM, the required return on an asset increases linearly with the market beta, that is, covariance between the asset's return and the market return. This model yields three additional effects which could be regarded as three forms of liquidity risks.

\footnotetext{
${ }^{6}$ Difficulties in testing this model arise from the fact that it makes predictions concerning conditional moments as is standard in asset pricing. See Hansen and Richard (1987), Cochrane (2001), and references therein. An unconditional version of (8) applies under stronger assumptions as discussed in Section 3.3.

${ }^{7}$ Empirically, Amihud and Mendelson $(1986,1989)$ find the required rate of return on NYSE stocks to increase with the relative bid-ask spread. This result is questioned for NYSE stocks by Eleswarapu and Reinganum (1993), but supported for NYSE stocks (especially for amortized spreads) by Chalmers and Kadlec (1998), and for Nasdaq stocks by Eleswarapu (1997). Gârleanu and Pedersen (2004) show theoretically that adverse-selection costs are priced only to the extent that they render allocations inefficient. The ability of a market to allocate assets efficiently may be related to market depth, and, consistent with this view, the required rate of return has been found to decrease with measures of depth (Brennan and Subrahmanyam, 1996; Amihud, 2002). Easley et al. (2002) find returns to increase with a measure of the probability of informed trading.
} 


\subsection{Three liquidity risks}

1. $\operatorname{cov}_{t}\left(c_{t+1}^{i}, c_{t+1}^{M}\right)$ : The first effect is that the return increases with the covariance between the asset's illiquidity and the market illiquidity. This is because investors want to be compensated for holding a security that becomes illiquid when the market in general becomes illiquid. The potential empirical significance of this pricing implication follows from the presence of a time-varying common factor in liquidity, which is documented by Chordia et al. (2000), Hasbrouck and Seppi (2001), and Huberman and Halka (1999). These papers find that most stocks' illiquidities are positively related to market illiquidity, so the required return should be raised by the commonality-in-liquidity effect. The effect of commonality in liquidity on asset prices is not studied, however, by these authors; we study this effect empirically in Section 4.

In this model, the risk premium associated with commonality in liquidity is caused by the wealth effects of illiquidity. Also, this risk premium would potentially apply in an economy in which investors can choose which securities to sell. In such a model, an investor who holds a security that becomes illiquid (that is, has a high $\operatorname{cost} c_{t}^{i}$ ) can choose to not trade this security and instead trade other (similar) securities. It is more likely that an investor can trade other (similar) securities, at low cost, if the liquidity of this asset does not co-move with the market liquidity. Hence, investors would require a return premium for assets with positive covariance between individual and market illiquidity.

2. $\operatorname{cov}_{t}\left(r_{t+1}^{i}, c_{t+1}^{M}\right)$ : The second effect on expected returns is due to covariation between a security's return and the market liquidity. We see that $\operatorname{cov}_{t}\left(r_{t+1}^{i}, c_{t+1}^{M}\right)$ affects required returns negatively because investors are willing to accept a lower return on an asset with a high return in times of market illiquidity. Related effects also arise in the theoretical models of Holmstrom and Tirole (2000), who examine implications of corporate demand for liquidity, and Lustig (2001), who studies the equilibrium implications of solvency constraints. Empirical support for this effect is provided by Pastor and Stambaugh (2003), who find that "the average return on stocks with high sensitivities to [market] liquidity exceeds that for stocks with low sensitivities by $7.5 \%$ annually, adjusted for exposures to the market return as well as size, value, and momentum factors." Sadka (2002) and Wang (2002) also present consistent evidence for this effect using alternative measures of liquidity.

3. $\operatorname{cov}_{t}\left(c_{t+1}^{i}, r_{t+1}^{M}\right)$ : The third effect on required returns is due to covariation between a security's illiquidity and the market return. This effect stems from the willingness of investors to accept a lower expected return on a security that is liquid in a down market. When the market declines, investors are poor and the ability to sell easily is especially valuable. Hence, an investor is willing to accept a discounted return on stocks with low illiquidity costs in states of poor market return. We find consistent evidence for this liquidity risk in the stock market in Section 4, and the effect seems economically important. Also, anecdotal evidence ${ }^{8}$ suggests that private

\footnotetext{
${ }^{8}$ For example, the Institute for Fiduciary Education (2002) characterizes private equity as an "illiquid asset class" and points out that "In down equity markets, exits are more difficult and little cash is returned." Source: http://www.ifecorp.com/Papers-PDFs/Wender1102.PDF.
} 
equity is illiquid during down markets, which, together with our model, may help explain the high average return documented by Ljungqvist and Richardson (2003).

Outside our model, intuition suggests that a low market return causes wealth problems for some investors, who then need to sell. If a selling investor holds securities that are illiquid at this time, then his problems are magnified. Consistent with this intuition, Lynch and Tan (2003) find that the liquidity premium is large if the transaction costs covary negatively with wealth shocks, among other conditions. This is consistent with our effect of $\operatorname{cov}_{t}\left(c_{t+1}^{i}, r_{t+1}^{M}\right)$ to the extent that $r^{M}$ proxies for wealth shocks. Lynch and Tan (2003) complement our paper by showing through calibration that, even if an investor chooses his holding period endogenously, the liquidity premium can be large $(3.55 \%$ in one calibration). They follow Constantinides (1986) in using a partial-equilibrium framework and defining the liquidity premium as the decrease in expected return that makes an investor indifferent between having access to the asset without transaction costs and the asset with transaction costs.

The three covariances thus provide a characterization of the liquidity risk of a security. We note that all these covariances can be accounted for by simply using the conditional CAPM in net returns as in (7). It is useful, however, to use gross returns and illiquidity as the basic inputs for several reasons: First, computing the net return is not straightforward since it depends on the investor's holding period, and the holding period may be different from the econometrician's sampling period. We explain in Section 4 how we overcome this problem. Second, the empirical liquidity literature is based on measures of gross return and illiquidity costs, and the model provides a theoretical foundation for the empirical relations between these security characteristics. Third, a pricing relation for gross returns and illiquidity, which is similar in spirit to (8), may hold in richer models in which net returns are not sufficient state variables. As argued above, additional liquidity effects outside the model suggest risk premia of the same sign for the covariance terms in (8). These additional liquidity effects also suggest that the size of the risk premia need not be identical across the covariance terms. To accommodate the possibility of a richer liquidity framework, we also consider a generalization of (8) in our empirical work in Section 4.

\subsection{Implications of persistence of liquidity}

This section shows that persistence of liquidity implies that liquidity predicts future returns and co-moves with contemporaneous returns.

Empirically, liquidity is time-varying and persistent, that is, $\rho^{C}>0$ (Amihud, 2002; Chordia et al., 2000, 2001a,b; Hasbrouck and Seppi, 2001; Huberman and Halka, 1999; Jones, 2001; Pastor and Stambaugh, 2003). This model shows that persistent liquidity implies that returns are predictable. Intuitively, high illiquidity today predicts high expected illiquidity next period, implying a high required return. The following proposition makes this intuition precise for a portfolio $q \in \mathbb{R}^{I}$. We use the obvious notation for portfolio dividend $D_{t}^{q}=q^{\top} D_{t}$, return $r_{t}^{q}=\frac{\sum_{i} q^{i}\left(D_{t}^{i}+P_{t}^{i}\right)}{\sum_{i} q^{i} P_{t-1}^{i}}$, and so on. 
Proposition 2. Suppose that $\rho^{C}>0$, and that $q \in \mathbb{R}^{I}$ is a portfolio with $E_{t}\left(P_{t+1}^{q}+\right.$ $\left.D_{t+1}^{q}\right)>\rho^{C} P_{t}^{q}$. Then, the conditional expected return increases with illiquidity,

$$
\frac{\partial}{\partial C_{t}^{q}} E_{t}\left(r_{t+1}^{q}-r^{f}\right)>0
$$

Proposition 2 relies on a mild technical condition, which is satisfied, for instance, for any portfolio with positive price and with $E_{t}\left(P_{t+1}^{q}+D_{t+1}^{q}\right) / P_{t}^{q} \geqslant 1$. The proposition states that the conditional expected return depends positively on the current illiquidity cost, that is, the current liquidity predicts the return.

Jones (2001) finds empirically that the expected annual stock market return increases with the previous year's bid-ask spread and decreases with the previous year's turnover. Amihud (2002) finds that illiquidity predicts excess return both for the market and for size-based portfolios, and Bekaert et al. (2003) find that illiquidity predicts returns in emerging markets.

Predictability of liquidity further implies a negative conditional covariance between contemporaneous returns and illiquidity. Naturally, when illiquidity is high, the required return is high also, which depresses the current price, leading to a low return. This intuition applies as long as liquidity is persistent $\left(\rho^{C}>0\right)$ and innovations in dividends and illiquidity are not too correlated $\left(q^{\top} \Sigma^{C D} q\right.$ low for a portfolio $q$ ), as is formalized in the following proposition.

Proposition 3. Suppose $q \in \mathbb{R}^{I}$ is a portfolio such that $\rho^{C}\left(r^{f} q^{\top} \Sigma^{C D} q+\left(r^{f}-\right.\right.$ $\left.\left.\rho^{D}\right) q^{\top} \Sigma^{C} q\right)>\left(r^{f}\right)^{2} q^{\top} \Sigma^{C D} q$. Then, returns are low when illiquidity increases,

$$
\operatorname{cov}_{t}\left(c_{t+1}^{q}, r_{t+1}^{q}\right)<0 \text {. }
$$

Consistent with this result, Chordia et al. (2001a), Jones (2001), and Pastor and Stambaugh (2003) find a negative relation between the market return and measures of market illiquidity, Amihud (2002) finds a negative relation between the return on size portfolios and their corresponding unexpected illiquidity, and Bekaert et al. (2003) find a negative relationship between illiquidity and returns for emerging markets.

\subsection{An unconditional liquidity-adjusted CAPM}

To estimate the liquidity-adjusted CAPM, we derive an unconditional version. An unconditional result obtains, for instance, under the assumption of independence over time of dividends and illiquidity costs. Empirically, however, illiquidity is persistent. Therefore, we rely instead on an assumption of constant conditional covariances of innovations in illiquidity and returns. ${ }^{9}$ This assumption yields the

\footnotetext{
${ }^{9}$ Alternatively, the same unconditional model can be derived by assuming a constant risk premium $\lambda$ and using the fact that for any random variables $X$ and $Y$, it holds that$$
E\left(\operatorname{cov}_{t}(X, Y)\right)=\operatorname{cov}\left(X-E_{t}(X), Y\right)=\operatorname{cov}\left(X-E_{t}(X), Y-E_{t}(Y)\right) .
$$

We note that the possible time-variation of risk premium is driven by constant absolute risk aversion in our model, but with constant relative risk aversion the risk premium is approximately constant. See Friend and Blume (1975).
} 
unconditional result that

$$
E\left(r_{t}^{i}-r_{t}^{f}\right)=E\left(c_{t}^{i}\right)+\lambda \beta^{1 i}+\lambda \beta^{2 i}-\lambda \beta^{3 i}-\lambda \beta^{4 i},
$$

where

$$
\begin{aligned}
\beta^{1 i} & =\frac{\operatorname{cov}\left(r_{t}^{i}, r_{t}^{M}-E_{t-1}\left(r_{t}^{M}\right)\right)}{\operatorname{var}\left(r_{t}^{M}-E_{t-1}\left(r_{t}^{M}\right)-\left[c_{t}^{M}-E_{t-1}\left(c_{t}^{M}\right)\right]\right)}, \\
\beta^{2 i} & =\frac{\operatorname{cov}\left(c_{t}^{i}-E_{t-1}\left(c_{t}^{i}\right), c_{t}^{M}-E_{t-1}\left(c_{t}^{M}\right)\right)}{\operatorname{var}\left(r_{t}^{M}-E_{t-1}\left(r_{t}^{M}\right)-\left[c_{t}^{M}-E_{t-1}\left(c_{t}^{M}\right)\right]\right)}, \\
\beta^{3 i} & =\frac{\operatorname{cov}\left(r_{t}^{i}, c_{t}^{M}-E_{t-1}\left(c_{t}^{M}\right)\right)}{\operatorname{var}\left(r_{t}^{M}-E_{t-1}\left(r_{t}^{M}\right)-\left[c_{t}^{M}-E_{t-1}\left(c_{t}^{M}\right)\right]\right)}, \\
\beta^{4 i} & =\frac{\operatorname{cov}\left(c_{t}^{i}-E_{t-1}\left(c_{t}^{i}\right), r_{t}^{M}-E_{t-1}\left(r_{t}^{M}\right)\right)}{\operatorname{var}\left(r_{t}^{M}-E_{t-1}\left(r_{t}^{M}\right)-\left[c_{t}^{M}-E_{t-1}\left(c_{t}^{M}\right)\right]\right)},
\end{aligned}
$$

and $\lambda=E\left(\lambda_{t}\right)=E\left(r_{t}^{M}-c_{t}^{M}-r^{f}\right)$. Next, we describe the empirical tests of this unconditional relation.

\section{Empirical results}

In this section, we estimate and test the liquidity-adjusted CAPM as specified in Equation (12). We do this in five steps:

(i) We estimate, in each month $t$ of our sample, a measure of illiquidity, $c_{t}^{i}$, for each individual security $i$. (Section 4.1).

(ii) We form a "market portfolio" and sets of 25 test portfolios sorted on the basis of illiquidity, illiquidity variation, size, and book-to-market by size, respectively. We compute the return and illiquidity for each portfolio in each month (Section 4.2).

(iii) For the market portfolio as well as the test portfolios, we estimate the innovations in illiquidity, $c_{t}^{p}-E_{t-1}\left(c_{t}^{p}\right)$ (Section 4.3).

(iv) Using these illiquidity innovations and returns, we estimate and analyze the liquidity betas (Section 4.4).

(v) Finally, we consider the empirical fit of the (unconditional) liquidity-adjusted CAPM by running cross-sectional regressions. To check the robustness of our results, we do the analysis with a number of different specifications (Section 4.5).

\subsection{The illiquidity measure}

Liquidity is (unfortunately) not an observable variable. There exist, however, many proxies for liquidity. Some proxies, such as the bid-ask spread, are based on market microstructure data, which is not available for a time series as long as is usually desirable for studying the effect on expected returns. Further, the bid-ask spread measures well the cost of selling a small number of shares, but it does not 
necessarily measure well the cost of selling many shares. We follow Amihud (2002) in estimating illiquidity using only daily data from the Center for Research in Security Prices (CRSP). In particular, Amihud (2002) defines the illiquidity of stock $i$ in month $t$ as

$$
I L L I Q_{t}^{i}=\frac{1}{D_{a y s}^{i}} \sum_{t=1}^{\text {Days }_{t}^{i}} \frac{\left|R_{t d}^{i}\right|}{V_{t d}^{i}},
$$

where $R_{t d}^{i}$ and $V_{t d}^{i}$ are, respectively, the return and dollar volume (in millions) on day $d$ in month $t$, and $D a y s_{t}^{i}$ is the number of valid observation days in month $t$ for stock $i$.

The intuition behind this illiquidity measure is as follows. A stock is illiquid - that is, has a high value of $I L L I Q_{t}^{i}$-if the stock's price moves a lot in response to little volume. In our model, illiquidity is the cost of selling and, as discussed in Section 2, real markets have several different selling costs including broker fees, bid-ask spreads, market impact, and search costs. Our empirical strategy is based on an assumption that ILLIQ is a valid instrument for the costs of selling, broadly interpreted. Consistent with this view, Amihud (2002) shows empirically that ILLIQ is positively related to measures of price impact and fixed trading costs over the time period in which he has the microstructure data. Similarly, Hasbrouck (2002) computes a measure of Kyle's lambda using microstructure data for NYSE, AMEX, and NASDAQ stocks, and finds that its Spearman (Pearson) correlation with ILLIQ in the cross-section of stocks is 0.737 (0.473). Hasbrouck (2002) concludes that "[a]mong the proxies considered here, the illiquidity measure [ILLIQ] appears to be the best." Furthermore, ILLIQ is closely related to the Amivest measure of illiquidity, which has often been used in the empirical microstructure literature.

There are two problems with using ILLIQ. First, it is measured in "percent per dollar," whereas the model is specified in terms of "dollar cost per dollar invested." This is a problem because it means that $I L L I Q$ is not stationary (e.g., inflation is ignored). Second, while $I L L I Q$ is an instrument for the cost of selling, it does not directly measure the cost of a trade. To solve these problems, we define a normalized measure of illiquidity, $c_{t}^{i}$, by

$$
c_{t}^{i}=\min \left(0.25+0.30 I L L I Q_{t}^{i} P_{t-1}^{M}, 30.00\right),
$$

where $P_{t-1}^{M}$ is the ratio of the capitalizations of the market portfolio at the end of month $t-1$ and of the market portfolio at the end of July 1962. The $P_{t-1}^{M}$ adjustment solves the first problem mentioned above, and it makes this measure of illiquidity relatively stationary. The coefficients 0.25 and 0.30 are chosen such that the crosssectional distribution of normalized illiquidity $\left(c_{t}^{i}\right)$ for size-decile portfolios has approximately the same level and variance as does the effective half spread-i.e. the difference between the transaction price and the midpoint of the prevailing bid-ask quote-reported by Chalmers and Kadlec (1998), Table 1. This normalized illiquidity is capped at a maximum value of $30 \%$ in order to ensure that our results are not driven by the extreme observations of $I L L I Q_{t}^{i}$. Furthermore, a per-trade cost 
greater than $30 \%$ seems unreasonable and is an artifact of the effect of low volume days on $I L L I Q_{t}^{i}$.

Chalmers and Kadlec (1998) report that the mean effective spread for size-decile portfolios of NYSE and AMEX stocks over the period 1983-1992 ranges from $0.29 \%$ to $3.41 \%$ with an average of $1.11 \%$. The normalized illiquidity, $c_{t}^{i}$, for identically formed portfolios has an average of $1.24 \%$, a standard deviation of $0.37 \%$, and matches the range as well as the cross-sectional variation reported by Chalmers and Kadlec (1998). This means that we can interpret the illiquidity measure $c_{t}^{i}$ as directly related to (a lower bound of) the per-trade cost.

Admittedly, this is a noisy measure of illiquidity. This makes it harder for us to find an empirical connection between return and illiquidity, and it can enhance omitted-variable problems. The noise is reduced by considering portfolios rather than individual stocks.

\subsection{Portfolios}

We employ daily return and volume data from CRSP from July 1st, 1962 until December 31st, 1999 for all common shares listed on NYSE and AMEX. To keep our liquidity measure consistent across stocks, we do not include Nasdaq since the volume data includes interdealer trades (and only starts in 1982). Also, we use bookto-market data based on the COMPUSTAT measure of book value. ${ }^{10}$

We form a market portfolio for each month $t$ during this sample period based on stocks with beginning-of-month price between $\$ 5$ and $\$ 1000$, and with at least 15 days of return and volume data in that month.

We form 25 illiquidity portfolios for each year $y$ during the period 1964 to 1999 by sorting stocks with price, at the beginning of the year, between $\$ 5$ and $\$ 1000$, and return and volume data in year $y-1$ for at least 100 days. ${ }^{11}$ We compute the annual illiquidity for each eligible stock as the average over the entire year $y-1$ of daily illiquidities, analogously to the monthly illiquidity calculation in (17). The eligible stocks are then sorted into 25 portfolios, $p \in\{1,2, \ldots, 25\}$, based on their year $y-1$ illiquidities.

Similarly, we form 25 illiquidity-variation portfolios (denoted " $\sigma$ (illiquidity) portfolios") by ranking the eligible stocks each year based on the standard deviation of daily illiquidity measures in the previous year, and 25 size portfolios by ranking stocks based on their market capitalization at the beginning of the year.

\footnotetext{
${ }^{10} \mathrm{We}$ are grateful to Joe Chen for providing us with data on book-to-market ratios. The book-to-market ratios are computed as described in Ang and Chen (2002): [For a given month] the book-to-market ratio is calculated using the most recently available fiscal year-end balance sheet data on COMPUSTAT. Following Fama and French (1993), we define "book value" as the value of common stockholders' equity, plus deferred taxes and investment tax credit, minus the book value of preferred stock. The book value is then divided by the market value on the day of the firm's fiscal year-end.

${ }^{11}$ Amihud (2002) and Pastor and Stambaugh (2003) employ similar requirements for the inclusion of stocks in their samples. These requirements help reduce the measurement error in the monthly illiquidity series.
} 
Finally, we form portfolios sorted first into five book-to-market quintiles and then into five size quintiles within the book-to-market groups. This sample is restricted to stocks with book-to-market data in year $y-1$. When considering the portfolio properties, we use the year-y book-to-market, averaging across stocks with available book-to-market data in that year.

For each portfolio $p$ (including the market portfolio), we compute its return in month $t$ as

$$
r_{t}^{p}=\sum_{i \text { in } p} w_{t}^{i p} r_{t}^{i}
$$

where the sum is taken over the stocks included in portfolio $p$ in month $t$, and where $w_{t}^{i p}$ are either equal weights or value-based weights, depending on the specification. ${ }^{12}$

Similarly, we compute the normalized illiquidity of a portfolio, $p$, as

$$
c_{t}^{p}=\sum_{i \text { in } p} w_{t}^{i p} c_{t}^{i}
$$

where, as above, $w_{t}^{i p}$ are either equal weights or value-based weights, depending on the specification.

The model's results are phrased in terms of value-weighted returns and valueweighted illiquidity for the market portfolio. Several studies, however, focus on equal-weighted return and illiquidity measures, for instance Amihud (2002) and Chordia et al. (2000). Computing the market return and illiquidity as equal-weighted averages is a way of compensating for the over-representation in our sample of large liquid securities, as compared to the "true" market portfolio in the economy. In particular, our sample does not include illiquid assets such as corporate bonds, private equity, real estate, and many small stocks, and these assets constitute a significant fraction of aggregate wealth. In particular, Heaton and Lucas (2000) report that stocks constitute only $13.6 \%$ of national wealth, while noncorporate (i.e. private) equity is $13.8 \%$, other financial wealth is $28.2 \%$, owner-occupied real estate is $33.3 \%$, and consumer durables is $11.1 \%$. Therefore, we focus in our empirical work on an equal-weighted market portfolio, although we also estimate the model with a value-weighted market portfolio for robustness. Also, we use both equal- and value-weighted averages for the test portfolios.

\subsection{Innovations in illiquidity}

Illiquidity is persistent. The autocorrelation of the market illiquidity, for instance, is 0.87 at a monthly frequency. Therefore, we focus on the innovations, $c_{t}^{p}-E_{t-1}\left(c_{t}^{p}\right)$,

\footnotetext{
${ }^{12}$ The returns, $r_{t}^{i}$, are adjusted for stock delisting to avoid survivorship bias, following Shumway (1997). In particular, the last return used is either the last return available on CRSP, or the delisting return, if available. While a last return for the stock of $-100 \%$ is naturally included in the study, a return of $-30 \%$ is assigned if the deletion reason is coded in CRSP as 500 (reason unavailable), 520 (went to OTC), 551-573 and 580 (various reasons), 574 (bankruptcy), and 584 (does not meet exchange financial guidelines). Shumway (1997) obtains that $-30 \%$ is the average delisting return, examining the OTC returns of delisted stocks.
} 
in illiquidity of a portfolio when computing its liquidity betas as explained in Section 3.3.

To compute these innovations, we first define the un-normalized illiquidity, truncated for outliers, of a portfolio $p$ as

$$
\overline{I L L I Q}_{t}^{p}:=\sum_{i \text { in } p} w_{t}^{i p} \min \left(I L L I Q_{t}^{i}, \frac{30.00-0.25}{0.30 P_{t-1}^{M}}\right),
$$

where $w_{t}^{i p}$ is the portfolio weight. As explained in Section 4.1, we normalize illiquidity to make it stationary and to put it on a scale corresponding to the cost of a single trade.

To predict market illiquidity, we run the following regression:

$$
\begin{aligned}
\left(0.25+0.30 \overline{\operatorname{LLLIQ}}{ }_{t}^{M} P_{t-1}^{M}\right)= & a_{0}+a_{1}\left(0.25+0.30 \overline{I L L I Q_{t-1}^{M}} P_{t-1}^{M}\right) \\
& +a_{2}\left(0.25+0.30 \overline{I L L I Q_{t-2}^{M}} P_{t-1}^{M}\right) \\
& +u_{t} .
\end{aligned}
$$

Note that the three terms inside parentheses in this specification correspond closely to $c_{t}^{M}, c_{t-1}^{M}$, and $c_{t-2}^{M}$, respectively, as given by (18) and (20), with the difference that the same date is used for the market index $\left(P_{t-1}^{M}\right)$ in all three terms. This is to ensure that we are measuring innovations only in illiquidity, not changes in $P^{M}$. Our results are robust to the specification of liquidity innovations and, in particular, employing other stock-market variables available at time $t-1$ does not improve significantly the explanatory power of the regression. Pastor and Stambaugh (2003) employ a specification to compute market liquidity innovations that is similar in spirit to the $\operatorname{AR}(2)$ specification in (22).

The residual, $u$, of the regression in (22) is interpreted as the market illiquidity innovation, $c_{t}^{M}-E_{t-1}\left(c_{t}^{M}\right)$, that is,

$$
c_{t}^{M}-E_{t-1}\left(c_{t}^{M}\right):=u_{t},
$$

and innovations in portfolio illiquidity are computed in the same way using the same AR coefficients.

For the market illiquidity series, the $\mathrm{AR}(2)$ specification has a $R^{2}$ of $78 \%$. The resulting innovations in market illiquidity, $c_{t}^{M}-E_{t-1}\left(c_{t}^{M}\right)$, have a standard deviation of $0.17 \%$. Fig. 1 plots the time series of these innovations, scaled to have unit standard deviation. The autocorrelation of these illiquidity innovations is low $(-0.03)$ and, visually, they appear stationary. Employing an $\mathrm{AR}(1)$ specification produces a significantly greater correlation of innovations $(-0.29)$, whereas employing an $\mathrm{AR}(3)$ specification produces little improvement in the explanatory power.

The measured innovations in market illiquidity are high during periods that anecdotally were characterized by liquidity crisis, for instance, in 5/1970 (Penn Central commercial paper crisis), 11/1973 (oil crisis), 10/1987 (stock market crash), 8/1990 (Iraqi invasion of Kuwait), 4,12/1997 (Asian crisis), and 6-10/1998 (Russian default and Long Term Capital Management crisis). The correlation between this 


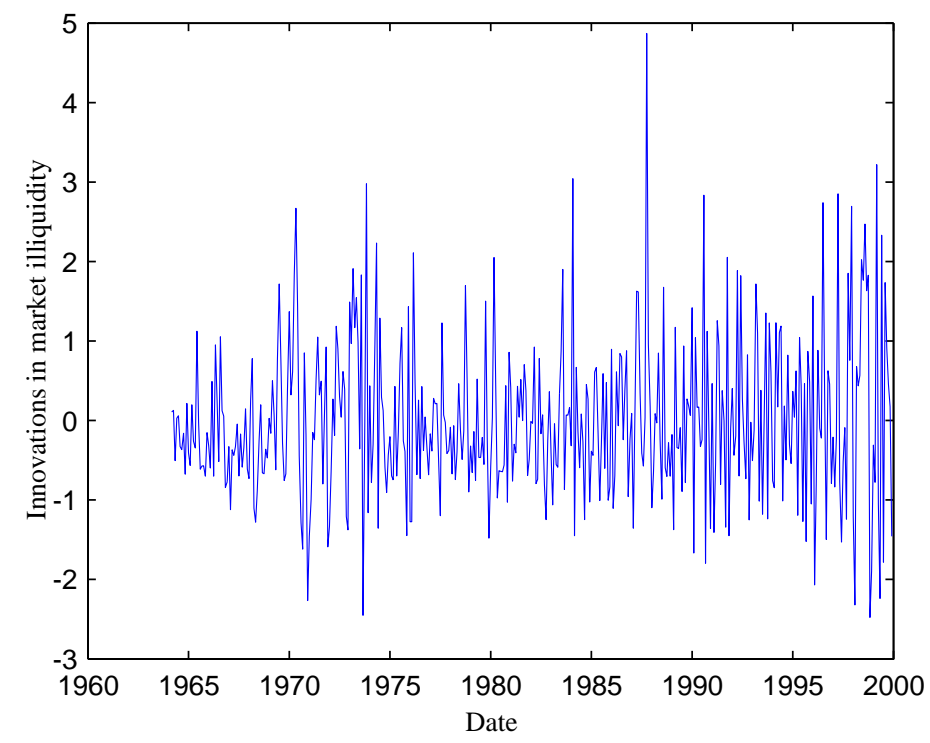

Fig. 1. Standardized innovations in market illiquidity from 1964-1999.

measure of innovations in market illiquidity and the measure of innovations in liquidity used by Pastor and Stambaugh (2003) is $-0.33 .{ }^{13}$ (The negative sign is due to the fact that Pastor and Stambaugh (2003) measure liquidity, whereas we follow Amihud (2002) in considering illiquidity.)

\subsection{Liquidity risk}

In this section, we present the descriptive statistics of liquidity risk, measured by the betas $\beta^{2 p}, \beta^{3 p}$, and $\beta^{4 p}$. We focus on the value-weighted illiquidity portfolios whose properties are reported in Table 1. Similar conclusions are drawn from examining the properties of equal-weighted illiquidity portfolios or size portfolios (not reported). The four betas, $\beta^{1 p}, \beta^{2 p}, \beta^{3 p}$, and $\beta^{4 p}$, for each portfolio are computed as per Eqs. (13)-(16) using the entire monthly time-series 1964 to 1999, where the illiquidity innovations are computed as described in Section 4.3 and the innovations in market portfolio returns are computed using an $\mathrm{AR}(2)$ that also employs available market characteristics at the beginning of the month (return, volatility, average illiquidity, log of average dollar volume, log of average turnover, all measured over the past six months, and log of one-month lagged market capitalization).

Table 1 shows that the sort on past illiquidity successfully produces portfolios with monotonically increasing average illiquidity from portfolio 1 through portfolio 25 . Not surprisingly, we see that illiquid stocks - that is, stocks with high average illiquidity $E\left(c^{p}\right)$ - tend to have a high volatility of stock returns, a low turnover, and

\footnotetext{
${ }^{13}$ We thank Pastor and Stambaugh for providing their data on innovations in market liquidity.
} 
Table 1

Properties of illiquidity portfolios

This table reports the properties of the odd-numbered portfolios of 25 value-weighted illiquidity portfolios formed each year during 1964-1999. The market beta $\left(\beta^{1 p}\right)$ and the liquidity betas $\left(\beta^{2 p}, \beta^{3 p}\right.$, and $\left.\beta^{4 p}\right)$ are computed using all monthly return and illiquidity observations for each portfolio and for an equal-weighted market portfolio; $t$-statistics are reported in parentheses. The standard deviation of a portfolio's illiquidity innovations is reported under the column of $\sigma\left(\Delta c^{p}\right)$. The average illiquidity, $E\left(c^{p}\right)$, the average excess return, $E\left(r^{e, p}\right)$, the turnover (trn), the market capitalization (size), and book-to-market (BM) are computed for each portfolio as time-series averages of the respective monthly characteristics. Finally, $\sigma\left(r^{p}\right)$ is the average of the standard deviation of daily returns for the portfolio's constituent stocks computed each month.

\begin{tabular}{|c|c|c|c|c|c|c|c|c|c|c|c|}
\hline & $\begin{array}{r}\beta^{1 p} \\
(\cdot 100)\end{array}$ & $\begin{array}{r}\beta^{2 p} \\
(\cdot 100)\end{array}$ & $\begin{array}{r}\beta^{3 p} \\
(\cdot 100)\end{array}$ & $\begin{array}{r}\beta^{4 p} \\
(\cdot 100)\end{array}$ & $\begin{array}{l}E\left(c^{p}\right) \\
(\%)\end{array}$ & $\begin{array}{l}\sigma\left(\Delta c^{p}\right) \\
(\%)\end{array}$ & $\begin{array}{l}E\left(r^{e, p}\right) \\
(\%)\end{array}$ & $\begin{array}{l}\sigma\left(r^{p}\right) \\
(\%)\end{array}$ & $\begin{array}{l}\operatorname{trn} \\
(\%)\end{array}$ & $\begin{array}{l}\text { Size } \\
\text { (bl\$) }\end{array}$ & BM \\
\hline 1 & $\begin{array}{c}55.10 \\
(14.54)\end{array}$ & $\begin{array}{c}0.00 \\
(0.08)\end{array}$ & $\begin{array}{c}-0.80 \\
(-5.90)\end{array}$ & $\begin{array}{l}-0.00 \\
(-0.10)\end{array}$ & 0.25 & 0.00 & 0.48 & 1.43 & 3.25 & 12.50 & 0.53 \\
\hline 3 & $\begin{array}{c}67.70 \\
(16.32)\end{array}$ & $\begin{array}{c}0.00 \\
(0.58)\end{array}$ & $\begin{array}{l}-1.05 \\
(-7.14)\end{array}$ & $\begin{array}{c}-0.03 \\
(-0.62)\end{array}$ & 0.26 & 0.00 & 0.39 & 1.64 & 4.19 & 2.26 & 0.72 \\
\hline 5 & $\begin{array}{c}74.67 \\
(20.44)\end{array}$ & $\begin{array}{c}0.00 \\
(1.27)\end{array}$ & $\begin{array}{c}-1.24 \\
(-7.43)\end{array}$ & $\begin{array}{l}-0.07 \\
(-1.36)\end{array}$ & 0.27 & 0.01 & 0.60 & 1.74 & 4.17 & 1.20 & 0.71 \\
\hline 7 & $\begin{array}{c}76.25 \\
(20.63)\end{array}$ & $\begin{array}{c}0.00 \\
(2.18)\end{array}$ & $\begin{array}{c}-1.27 \\
(-7.49)\end{array}$ & $\begin{array}{l}-0.10 \\
(-2.03)\end{array}$ & 0.29 & 0.01 & 0.57 & 1.83 & 4.14 & 0.74 & 0.73 \\
\hline 9 & $\begin{array}{c}81.93 \\
(33.25)\end{array}$ & $\begin{array}{c}0.01 \\
(3.79)\end{array}$ & $\begin{array}{c}-1.37 \\
(-8.00)\end{array}$ & $\begin{array}{l}-0.18 \\
(-3.74)\end{array}$ & 0.32 & 0.02 & 0.71 & 1.86 & 3.82 & 0.48 & 0.73 \\
\hline 11 & $\begin{array}{c}84.59 \\
(34.21)\end{array}$ & $\begin{array}{c}0.01 \\
(5.07)\end{array}$ & $\begin{array}{l}-1.41 \\
(-7.94)\end{array}$ & $\begin{array}{c}-0.33 \\
(-5.85)\end{array}$ & 0.36 & 0.04 & 0.73 & 1.94 & 3.87 & 0.33 & 0.76 \\
\hline 13 & $\begin{array}{c}85.29 \\
(34.15)\end{array}$ & $\begin{array}{c}0.01 \\
(6.84)\end{array}$ & $\begin{array}{c}-1.47 \\
(-8.01)\end{array}$ & $\begin{array}{c}-0.40 \\
(-7.46)\end{array}$ & 0.43 & 0.05 & 0.77 & 1.99 & 3.47 & 0.24 & 0.77 \\
\hline 15 & $\begin{array}{c}88.99 \\
(42.88)\end{array}$ & $\begin{array}{c}0.02 \\
(6.87)\end{array}$ & $\begin{array}{l}-1.61 \\
(-8.35)\end{array}$ & $\begin{array}{l}-0.70 \\
(-8.45)\end{array}$ & 0.53 & 0.08 & 0.85 & 2.04 & 3.20 & 0.17 & 0.83 \\
\hline 17 & $\begin{array}{c}87.89 \\
(27.54)\end{array}$ & $\begin{array}{c}0.04 \\
(8.16)\end{array}$ & $\begin{array}{c}-1.59 \\
(-8.18)\end{array}$ & $\begin{array}{c}-0.98 \\
(-9.30)\end{array}$ & 0.71 & 0.13 & 0.80 & 2.11 & 2.96 & 0.13 & 0.88 \\
\hline 19 & $\begin{array}{c}87.50 \\
(40.74)\end{array}$ & $\begin{array}{c}0.05 \\
(7.63)\end{array}$ & $\begin{array}{c}-1.58 \\
(-8.75)\end{array}$ & $\begin{array}{l}-1.53 \\
(-8.77)\end{array}$ & 1.01 & 0.21 & 0.83 & 2.13 & 2.68 & 0.09 & 0.92 \\
\hline 21 & $\begin{array}{c}92.73 \\
(37.85)\end{array}$ & $\begin{array}{c}0.09 \\
(7.33)\end{array}$ & $\begin{array}{c}-1.69 \\
(-8.34)\end{array}$ & $\begin{array}{l}-2.10 \\
(-6.11)\end{array}$ & 1.61 & 0.34 & 1.13 & 2.28 & 2.97 & 0.06 & 0.99 \\
\hline 23 & $\begin{array}{c}94.76 \\
(39.71)\end{array}$ & $\begin{array}{c}0.19 \\
(6.85)\end{array}$ & $\begin{array}{l}-1.71 \\
(-8.68)\end{array}$ & $\begin{array}{l}-3.35 \\
(-5.91)\end{array}$ & 3.02 & 0.62 & 1.12 & 2.57 & 2.75 & 0.04 & 1.09 \\
\hline 25 & $\begin{array}{c}84.54 \\
(20.86)\end{array}$ & $\begin{array}{c}0.42 \\
(6.40)\end{array}$ & $\begin{array}{c}-1.69 \\
(-8.23)\end{array}$ & $\begin{array}{c}-4.52 \\
(-3.35)\end{array}$ & 8.83 & 1.46 & 1.10 & 2.87 & 2.60 & 0.02 & 1.15 \\
\hline
\end{tabular}

a small market capitalization. Furthermore, we find that illiquid stocks also have high liquidity risk - they have large values of $\beta^{2 p}$ and large negative values of $\beta^{3 p}$ and $\beta^{4 p}$. In other words, a stock, which is illiquid in absolute terms $\left(c^{p}\right)$, also tends to have a lot of commonality in liquidity with the market $\left(\operatorname{cov}\left(c^{p}, c^{M}\right)\right)$, a lot of return sensitivity to market liquidity $\left(\operatorname{cov}\left(r^{p}, c^{M}\right)\right)$, and a lot of liquidity sensitivity to market returns $\left(\operatorname{cov}\left(c^{p}, r^{M}\right)\right)$. This result is interesting on its own since it is consistent with the notion of flight to liquidity. We note that all of the betas are estimated with a small error (i.e., a small asymptotic variance). Indeed, almost all of the betas are statistically significant at conventional levels. 
A liquidity beta is proportional to the product of the correlation between its respective arguments and their standard deviations. As noted before, more illiquid stocks have greater volatility of returns. Furthermore, since illiquidity is bounded below by zero, it is natural that more illiquid stocks also have more volatile illiquidity innovations. This is verified in Table 1 which shows that the standard deviation of portfolio illiquidity innovations, $\sigma\left(\Delta c^{p}\right)$, increases monotonically in portfolio illiquidity. However, the higher variability of returns and illiquidity innovations are not the sole drivers of the positive relation between illiquidity and liquidity risk. The correlation coefficients between $c^{p}$ and $c^{M}\left(r^{p}\right.$ and $c^{M}$ ) are also increasing (decreasing) in portfolio illiquidity. The correlation coefficients between $c^{p}$ and $r^{M}$ are decreasing in illiquidity between portfolios 1-15 and are gradually increasing thereafter. Nevertheless, the variability of $c^{p}$ ensures that the covariances between $c^{p}$ and $r^{M}$ are decreasing in illiquidity. (These correlations are not reported in the table for sake of brevity.)

The collinearity of measures of liquidity risk is confirmed by considering the correlation among the betas, reported in Table 2 . The collinearity problem is not just a property of the liquidity-sorted portfolios; it also exists at an individual stock level as is seen in Table 3. The collinearity at the stock level is smaller, which could be due in part to larger estimation errors. While this collinearity is theoretically intriguing, it makes it hard to empirically distinguish the separate effects of illiquidity and the individual liquidity betas.

\subsection{How liquidity risk affects returns}

In this section, we study how liquidity risk affects expected returns. We do this by running cross-sectional regressions on our test portfolios using a GMM framework that takes into account the pre-estimation of the betas (as in Cochrane, 2001). Standard errors are computed using the Newey and West (1987) method with two lags. Our point estimates are the same as those derived using OLS (either in a pooled regression or using the Fama and MacBeth (1973) method), and our standard errors correspond to those of Shanken (1992) except that the GMM method also takes serial correlation into account.

Illiquidity and $\sigma$ (illiquidity) portfolios. The potential effect of liquidity and liquidity risk is, of course, detected by considering portfolios that differ in their liquidity attributes. Hence, we consider first the liquidity-adjusted CAPM (12) for portfolios sorted by illiquidity and the illiquidity variation.

To impose the model-implied constraint that the risk premia of the different betas is the same, we define the "net beta" as

$$
\beta^{\text {net }, p}:=\beta^{1 p}+\beta^{2 p}-\beta^{3 p}-\beta^{4 p} .
$$

With this definition, the liquidity-adjusted CAPM becomes

$$
E\left(r_{t}^{p}-r_{t}^{f}\right)=\alpha+\kappa E\left(c_{t}^{p}\right)+\lambda \beta^{\text {net }, p},
$$

where we allow a nonzero intercept, $\alpha$, in the estimation, although the model implies that the intercept is zero. Also, in our model $\kappa=1$. This is because investors incur 
Table 2

Beta correlations for illiquidity portfolios

This table reports the correlations of $\beta^{1 p}, \beta^{2 p}, \beta^{3 p}$, and $\beta^{4 p}$ for the 25 value-weighted illiquidity portfolios formed for each year during 1964-1999.

\begin{tabular}{lllrr}
\hline & $\beta^{1 p}$ & $\beta^{2 p}$ & $\beta^{3 p}$ & \multicolumn{1}{c}{$\beta^{4 p}$} \\
\hline$\beta^{1 p}$ & 1.000 & 0.441 & -0.972 & -0.628 \\
$\beta^{2 p}$ & 1.000 & -0.573 & -0.941 \\
$\beta^{3 p}$ & & 1.000 & 0.726 \\
$\beta^{4 p}$ & & & 1.000 \\
\hline
\end{tabular}

Table 3

Beta correlations for individual stocks

This table reports the correlations of $\beta^{1 i}, \beta^{2 i}, \beta^{3 i}$, and $\beta^{4 i}$ for the common shares listed on NYSE and AMEX during the period 1964-1999. The correlations are computed annually for all eligible stocks in a year and then averaged over the sample period. The four betas are computed for each stock using all monthly return and illiquidity observations for the stock and the market portfolio.

\begin{tabular}{lllrr}
\hline & $\beta^{1 i}$ & $\beta^{2 i}$ & $\beta^{3 i}$ & \multicolumn{1}{c}{$\beta^{4 i}$} \\
\hline$\beta^{1 i}$ & 1.000 & 0.020 & -0.685 & -0.164 \\
$\beta^{2 i}$ & & 1.000 & -0.072 & -0.270 \\
$\beta^{3 i}$ & & 1.000 & 0.192 \\
$\beta^{4 i}$ & & & 1.000 \\
\hline
\end{tabular}

the illiquidity cost exactly once each model period. Our monthly estimation period is, however, different from a typical investor's holding period-the period implicitly considered in the model. When the estimation period is $\kappa$ times the holding period, then the estimated $E\left(r_{t}^{p}-r_{t}^{f}\right)$ is approximately $\kappa$ times the expected holding period return, and the estimated $\beta^{\text {net, } p}$ is assumed to be approximately $\kappa$ times the holdingperiod net beta. This is because a $\kappa$-period return (or illiquidity innovation) is approximately a sum of $\kappa$ one-period returns (or illiquidity innovations), and because returns and illiquidity innovations have low correlation across time. The illiquidity, $E\left(c^{p}\right)$, however, does not scale with time period because it is an average of daily illiquidities (not a sum of such terms). Therefore, the $E\left(c^{p}\right)$ term is scaled by $\kappa$ in (25) to adjust for the difference between estimation periods and holding periods.

The average holding period is proxied empirically by the period over which all shares are turned over once. Hence, we calibrate $\kappa$ as the average monthly turnover across all stocks in the sample. In the sample of liquidity portfolios, $\kappa$ is calibrated to 0.034 , which corresponds to a holding period of $1 / 0.034 \cong 29$ months. The expected illiquidity, $E\left(c_{t}^{p}\right)$, is computed as the portfolio's average illiquidity. To run the regression (25) with a fixed $\kappa$, we treat the net return, $E\left(r_{t}^{p}-r_{t}^{f}\right)-\kappa E\left(c_{t}^{p}\right)$, as the dependent variable. However, all $R^{2}$ are based on the same dependent variable, namely, $E\left(r_{t}^{p}-r_{t}^{f}\right)$. Note that the structure of the liquidity-adjusted CAPM and the 
calibration of $\kappa$ make the estimation different from the typical cross-sectional regression study in which the asset-pricing relationship is backed out from the return series and data on security characteristics such as beta, size, book-to-market, etc.

The liquidity-adjusted CAPM (25) has only one risk premium, $\lambda$, that needs to be estimated as in the standard CAPM. Here, the risk factor is the net beta instead of the standard market beta. Hence, the empirical improvement in fit relative to the standard CAPM is not achieved by adding factors (or otherwise adding degrees of freedom), but simply by making a liquidity adjustment.

The estimated results for Eq. (25) are reported in line 1 of Table 4, with illiquidity portfolios in Panel A and $\sigma$ (illiquidity) portfolios in Panel B. With either portfolio, the risk premium $\lambda$ is positive and significant at a $1 \%$ level and $\alpha$ is insignificant, both results lending support to our model. The $R^{2}$ of the liquidity-adjusted CAPM is high relative to the standard CAPM, reported in line 3 . In line 2, we estimate the liquidityadjusted CAPM with $\kappa$ as a free parameter, which results in only modest changes in $\kappa$ and $\lambda$.

While the improvement in fit of the liquidity-adjusted CAPM over the CAPM is encouraging, it does not constitute a test of the effect of liquidity risk. To isolate the effect of liquidity risk $\left(\beta^{2}, \beta^{3}\right.$, and $\left.\beta^{4}\right)$ over liquidity level $(E(c))$ and market risk $\left(\beta^{1}\right)$, we consider the relation

$$
E\left(r_{t}^{p}-r_{t}^{f}\right)=\alpha+\kappa E\left(c_{t}^{p}\right)+\lambda^{1} \beta^{1 p}+\lambda \beta^{\text {net }, p} .
$$

In line 4 , this relation is estimated with $\kappa$ at its calibrated value. We see that $\beta^{\text {net }}$ is insignificant for illiquidity portfolios, but significant for $\sigma$ (illiquidity) portfolios. In line 5 , the relation is estimated with $\kappa$ as a free parameter. In this regression, the support for the model is stronger in that $\beta^{\text {net }}$ is significant with either portfolio. We note that $\kappa$ is estimated to be negative in Panel A, although it is statistically insignificant. Since the model implies that $\kappa$ should be positive, we estimate in line 6 with the restriction that $\kappa=0$. With this specification, $\beta^{\text {net }}$ remains significant in both panels. In conclusion, there is some evidence that liquidity risk matters over and above market risk and liquidity level. The collinearity problems imply, however, that this evidence is weak.

We note that a negative coefficient on $\beta^{1}$ does not imply a negative risk premium on market risk since $\beta^{1}$ is also contained in $\beta^{\text {net }}$. Rather, a negative coefficient suggests that liquidity risk may have a higher risk premium than market risk. For instance, line 4 of Table 4A means that

$$
\begin{aligned}
E\left(r_{t}^{p}-r_{t}^{f}\right) & =-0.333+0.034 E\left(c_{t}^{p}\right)-3.181 \beta^{1 p}+4.334 \beta^{\text {net }, p} \\
& =-0.333+0.034 E\left(c_{t}^{p}\right)+1.153 \beta^{1 p}+4.334\left(\beta^{2 p}-\beta^{3 p}-\beta^{4 p}\right) .
\end{aligned}
$$

Finally, in line 7 we allow all of the betas to have different risk premia $\lambda^{i}$, and in line 8 we further let $\kappa$ be a free parameter. That is, lines $7-8$ estimate the generalized relation

$$
E\left(r_{t}^{p}-r_{t}^{f}\right)=\alpha+\kappa E\left(c_{t}^{p}\right)+\lambda^{1} \beta^{1 p}+\lambda^{2} \beta^{2 p}+\lambda^{3} \beta^{3 p}+\lambda^{4} \beta^{4 p}
$$

without the model restrictions that $\lambda^{1}=\lambda^{2}=-\lambda^{3}=-\lambda^{4}$. We see that the multicollinearity problems are severe, and, hence, statistical identification of the separate 
Table 4

Illiquidity and $\sigma$ (illiquidity) portfolios

This table reports the estimated coefficients from cross-sectional regressions of the liquidity-adjusted CAPM for 25 value-weighted portfolios using monthly data during 1964-1999 with an equal-weighted market portfolio. We consider special cases of the relation

$$
E\left(r_{t}^{p}-r_{t}^{f}\right)=\alpha+\kappa E\left(c_{t}^{p}\right)+\lambda^{1} \beta^{1 p}+\lambda^{2} \beta^{2 p}+\lambda^{3} \beta^{3 p}+\lambda^{4} \beta^{4 p}+\lambda \beta^{\text {net }, p},
$$

where $\beta^{\text {net }, p}=\beta^{1 p}+\beta^{2 p}-\beta^{3 p}-\beta^{4 p}$. In some specifications, $\kappa$ is set to be the average monthly turnover. The $t$-statistic, reported in the parentheses, is estimated using a GMM framework that takes into account the pre-estimation of the betas. The $R^{2}$ is obtained in a single cross-sectional regression, and the adjusted $R^{2}$ is reported in parentheses.

\begin{tabular}{|c|c|c|c|c|c|c|c|c|}
\hline & Constant & $E\left(c^{p}\right)$ & $\beta^{1 p}$ & $\beta^{2 p}$ & $\beta^{3 p}$ & $\beta^{4 p}$ & $\beta^{\text {net }, p}$ & $R^{2}$ \\
\hline \multicolumn{9}{|c|}{ Panel A: illiquidity portfolios } \\
\hline 1 & $\begin{array}{l}-0.556 \\
(-1.450)\end{array}$ & $\begin{array}{l}0.034 \\
(-)\end{array}$ & & & & & $\begin{array}{l}1.512 \\
(2.806)\end{array}$ & $\begin{array}{l}0.732 \\
(0.732)\end{array}$ \\
\hline 2 & $\begin{array}{l}-0.512 \\
(-1.482)\end{array}$ & $\begin{array}{l}0.042 \\
(2.210)\end{array}$ & & & & & $\begin{array}{l}1.449 \\
(2.532)\end{array}$ & $\begin{array}{l}0.825 \\
(0.809)\end{array}$ \\
\hline 3 & $\begin{array}{l}-0.788 \\
(-1.910)\end{array}$ & & $\begin{array}{c}1.891 \\
(3.198)\end{array}$ & & & & & $\begin{array}{l}0.653 \\
(0.638)\end{array}$ \\
\hline 4 & $\begin{array}{l}-0.333 \\
(-0.913)\end{array}$ & $\begin{array}{l}0.034 \\
(-)\end{array}$ & $\begin{array}{c}-3.181 \\
(-0.998)\end{array}$ & & & & $\begin{array}{l}4.334 \\
(1.102)\end{array}$ & $\begin{array}{l}0.843 \\
(0.836)\end{array}$ \\
\hline 5 & $\begin{array}{l}0.005 \\
(0.013)\end{array}$ & $\begin{array}{l}-0.032 \\
(-0.806)\end{array}$ & $\begin{array}{l}-13.223 \\
(-1.969)\end{array}$ & & & & $\begin{array}{l}13.767 \\
(2.080)\end{array}$ & $\begin{array}{l}0.878 \\
(0.861)\end{array}$ \\
\hline 6 & $\begin{array}{l}-0.160 \\
(-0.447)\end{array}$ & & $\begin{array}{c}-8.322 \\
(-2.681)\end{array}$ & & & & $\begin{array}{l}9.164 \\
(3.016)\end{array}$ & $\begin{array}{l}0.870 \\
(0.858)\end{array}$ \\
\hline 7 & $\begin{array}{l}-0.089 \\
(-0.219)\end{array}$ & $\begin{array}{l}0.034 \\
(-)\end{array}$ & $\begin{array}{c}0.992 \\
(0.743)\end{array}$ & $\begin{array}{r}-153.369 \\
(-1.287)\end{array}$ & $\begin{array}{l}7.112 \\
(0.402)\end{array}$ & $\begin{array}{l}-17.583 \\
(-1.753)\end{array}$ & & $\begin{array}{l}0.881 \\
(0.865)\end{array}$ \\
\hline 8 & $\begin{array}{l}-0.089 \\
(-0.157)\end{array}$ & $\begin{array}{l}0.033 \\
(0.166)\end{array}$ & $\begin{array}{c}0.992 \\
(0.468)\end{array}$ & $\begin{array}{r}-151.152 \\
(-0.280)\end{array}$ & $\begin{array}{l}7.087 \\
(0.086)\end{array}$ & $\begin{array}{l}-17.542 \\
(-1.130)\end{array}$ & & $\begin{array}{l}0.881 \\
(0.850)\end{array}$ \\
\hline \multicolumn{9}{|c|}{ Panel B: $\sigma$ (illiquidity) portfolios } \\
\hline 1 & $\begin{array}{l}-0.528 \\
(-1.419)\end{array}$ & $\begin{array}{l}0.035 \\
(-)\end{array}$ & & & & & $\begin{array}{l}1.471 \\
(2.817)\end{array}$ & $\begin{array}{l}0.865 \\
(0.865)\end{array}$ \\
\hline 2 & $\begin{array}{l}-0.363 \\
(-1.070)\end{array}$ & $\begin{array}{l}0.062 \\
(2.433)\end{array}$ & & & & & $\begin{array}{l}1.243 \\
(2.240)\end{array}$ & $\begin{array}{l}0.886 \\
(0.875)\end{array}$ \\
\hline 3 & $\begin{array}{l}-0.827 \\
(-2.027)\end{array}$ & & $\begin{array}{c}1.923 \\
(3.322)\end{array}$ & & & & & $\begin{array}{l}0.726 \\
(0.714)\end{array}$ \\
\hline 4 & $\begin{array}{l}-0.014 \\
(-0.037)\end{array}$ & $\begin{array}{l}0.035 \\
(-)\end{array}$ & $\begin{array}{c}-7.113 \\
(-1.939)\end{array}$ & & & & $\begin{array}{l}7.772 \\
(2.615)\end{array}$ & $\begin{array}{l}0.917 \\
(0.914)\end{array}$ \\
\hline 5 & $\begin{array}{l}0.094 \\
(0.235)\end{array}$ & $\begin{array}{l}0.007 \\
(0.158)\end{array}$ & $\begin{array}{l}-11.013 \\
(-2.080)\end{array}$ & & & & $\begin{array}{l}11.467 \\
(2.480)\end{array}$ & $\begin{array}{l}0.924 \\
(0.914)\end{array}$ \\
\hline 6 & $\begin{array}{l}0.119 \\
(0.305)\end{array}$ & & $\begin{array}{l}-11.914 \\
(-2.413)\end{array}$ & & & & $\begin{array}{l}12.320 \\
(2.608)\end{array}$ & $\begin{array}{l}0.924 \\
(0.917)\end{array}$ \\
\hline 7 & $\begin{array}{l}0.464 \\
(0.913)\end{array}$ & $\begin{array}{l}0.035 \\
(-)\end{array}$ & $\begin{array}{c}-1.105 \\
(-0.728)\end{array}$ & $\begin{array}{l}-83.690 \\
(-0.663)\end{array}$ & $\begin{array}{l}-74.538 \\
(-1.175)\end{array}$ & $\begin{array}{l}-14.560 \\
(-1.662)\end{array}$ & & $\begin{array}{l}0.940 \\
(0.931)\end{array}$ \\
\hline 8 & $\begin{array}{l}0.459 \\
(0.565)\end{array}$ & $\begin{array}{l}0.148 \\
(0.140)\end{array}$ & $\begin{array}{c}-1.125 \\
(-0.485)\end{array}$ & $\begin{array}{r}-390.588 \\
(-0.140)\end{array}$ & $\begin{array}{l}-73.552 \\
(-1.943)\end{array}$ & $\begin{array}{l}-21.688 \\
(-0.335)\end{array}$ & & $\begin{array}{l}0.942 \\
(0.927)\end{array}$ \\
\hline
\end{tabular}


effects of the different liquidity risks is difficult. Of course, we must also entertain the possibility that not all of these risk factors are empirically relevant.

The empirical fit of the standard CAPM is illustrated in the top left panel of Fig. 2 for illiquidity portfolios and of Fig. 3 for $\sigma$ (illiquidity) portfolios. The top right and bottom panels show, respectively, the fit of the constrained and unconstrained liquidity-adjusted CAPM, that is, lines 1 and 8 , respectively, from Table 4 . We see that the liquidity adjustment improves the fit especially for the illiquid portfolios, consistent with what our intuition would suggest. We note that the number of free parameters is the same in the top right and top left panels, so the improvement in fit is not a consequence of more degrees of freedom.

Economic significance of results. It is interesting to consider the economic significance of liquidity risk. To get a perspective on the magnitude of the effect, we compute the annual return premium required to hold illiquid rather than liquid securities. This is computed as the product of the risk premium and the difference in liquidity risk across liquidity portfolios. If we use the unrestricted model in line 8 of
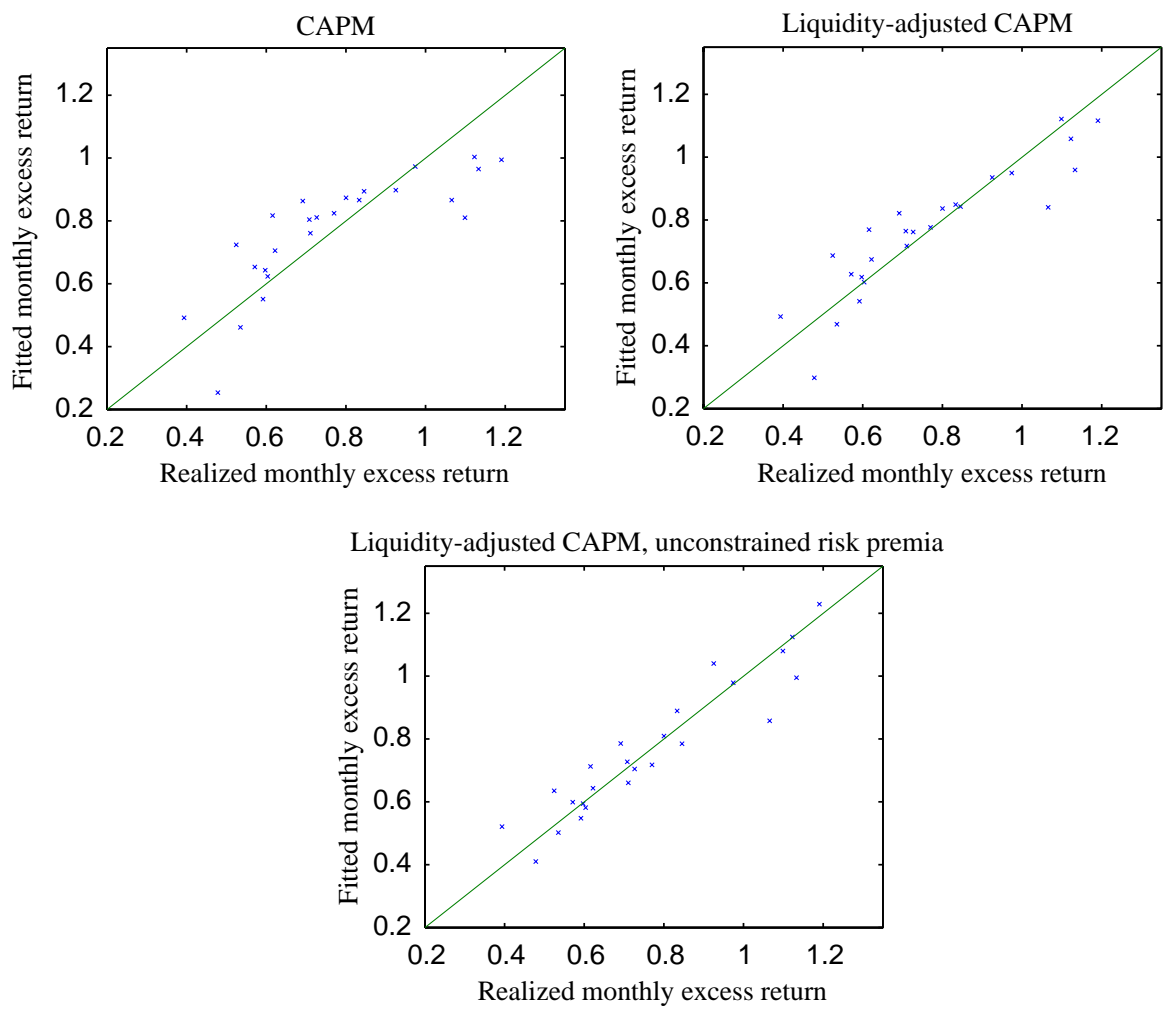

Fig. 2. Illiquidity portfolios: the top left panel shows the fitted CAPM returns vs. realized returns using monthly data 1964-1999 for value-weighted illiquidity portfolios. The top right panel shows the same for the liquidity-adjusted CAPM, and the lower panel shows the relation for the liquidity-adjusted CAPM with unconstrained risk premia. 

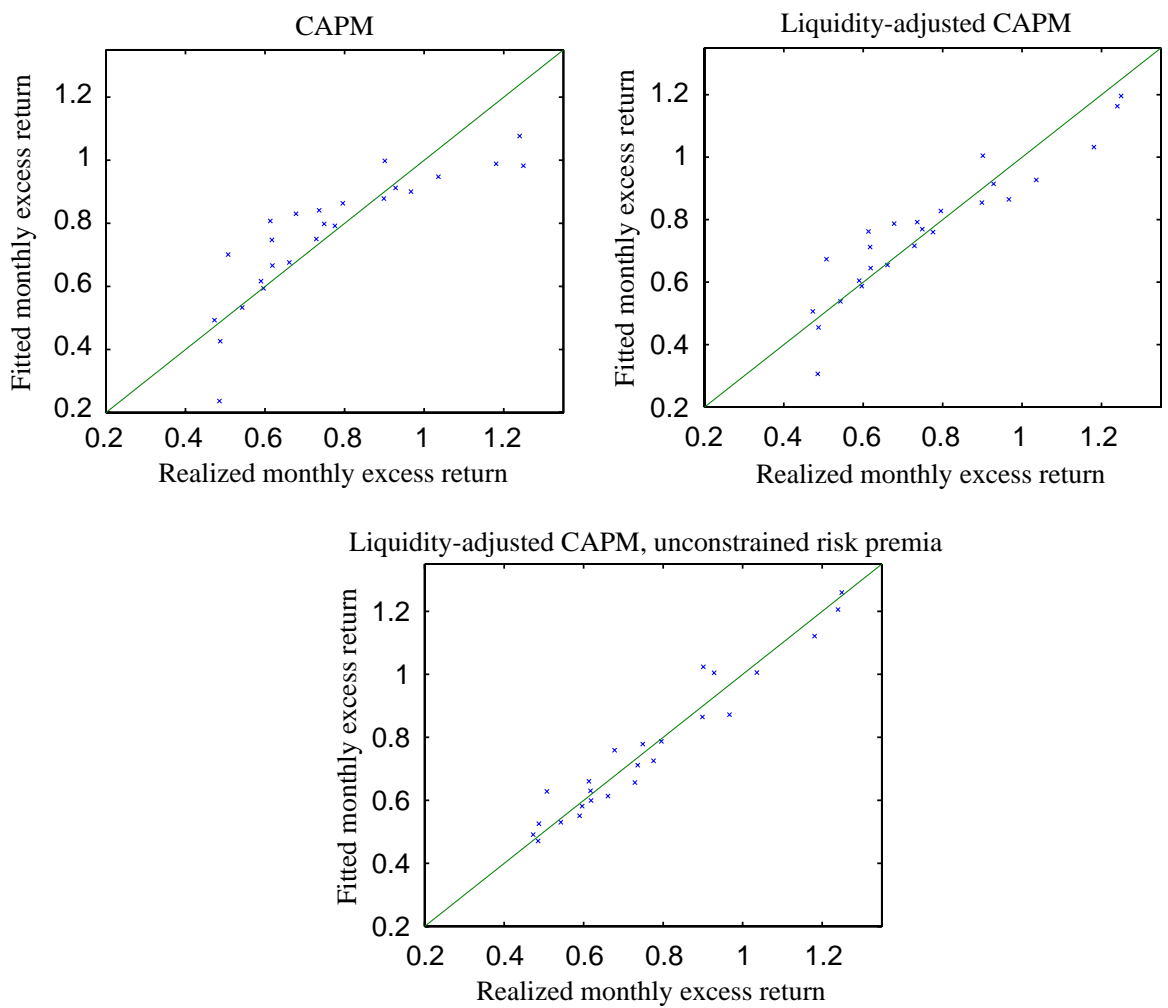

Fig. 3. $\sigma$ (illiquidity) portfolios: the top left panel shows the fitted CAPM returns vs. realized returns using monthly data 1964-1999 for value weighted $\sigma$ (illiquidity) portfolios. The top right panel shows the same for the liquidity-adjusted CAPM, and the lower panel shows the relation for the liquidity-adjusted CAPM with unconstrained risk premia.

Table 4A, then our estimates are very noisy because of the multicollinearity problem. Instead, the benefit of having an economic model is that we can impose its structure and can get relatively tight estimates. Hence, we use the calibrated value of $\kappa$ and the common risk premium, $\lambda=1.512$, from line 1 . Of course, when interpreting the results, one must bear in mind that they rely on the validity of the model.

The difference in annualized expected returns between portfolio 1 and 25 that can be attributed to a difference in $\beta^{2}$, the commonality between the portfolio illiquidity and market illiquidity, is

$$
\lambda\left(\beta^{2, p_{25}}-\beta^{2, p_{1}}\right) 12=0.08 \% .
$$

Similarly, the annualized return difference stemming from the difference in $\beta^{3}$, the sensitivity of the portfolio return to market illiquidity, is

$$
-\lambda\left(\beta^{3, p_{25}}-\beta^{3, p_{1}}\right) 12=0.16 \%,
$$


and the effect of $\beta^{4}$, the sensitivity of the portfolio illiquidity to market return, is

$$
-\lambda\left(\beta^{4, p_{25}}-\beta^{4, p_{1}}\right) 12=0.82 \% .
$$

The total effect of liquidity risk is therefore $1.1 \%$ per year. Using the standard error of the estimates of $\lambda$ and the betas, the $95 \%$ confidence interval for the total effect of $\beta^{2}-\beta^{3}-\beta^{4}$ is $[0.24 \%, 1.88 \%]$. Hence, under the model restrictions and using the calibrated $\kappa$, the effect of liquidity risk is significantly different from zero.

Interestingly, of the three liquidity risks the effect of $\beta^{4}$, the covariation of a security's illiquidity to market returns, appears to have the largest economic impact on expected returns. (Also, it has the highest $t$-statistics in the unrestricted regression of lines 7-8 in Table 4). This liquidity risk has not been studied before either theoretically or empirically.

The difference in annualized expected returns between portfolios 1 and 25 that can be attributed to a difference in the expected illiquidity, $E(c)$, is $3.5 \%$, using the calibrated coefficient. The overall effect of expected illiquidity and liquidity risk is thus $4.6 \%$ per year.

While the magnitude of liquidity risk is economically significant, it is lower than the magnitude estimated by Pastor and Stambaugh (2003). This could be due to the fact that they employ a different measure of liquidity, or due to the fact that they sort portfolios based on liquidity risk (in their case, $\beta^{3}$ ) whereas we sort based on the level of liquidity. Also, this could be because they do not control for the level of illiquidity which has been shown to command a significant premium in a number of studies including Amihud and Mendelson (1986), Brennan and Subrahmanyam (1996), Brennan et al. (1998), Datar et al. (1998), Swan (2002), and Dimson and Hanke (2002). Finally, the difference could also arise because we restrict the risk premia on different liquidity betas to be the same. For instance, the magnitude of the risk premium related to $\beta^{4}$ is estimated to be higher in lines $7-8$ of Table $4 \mathrm{~A}$. This higher risk premium results in a per-year effect of about $9 \%$ from $\beta^{4}$ alone. ${ }^{14}$

The collinearity between liquidity and liquidity risk implies that the most robust number is their overall effect. Further, our results suggest that studies that focus on the separate effect of liquidity (or liquidity risk) can possibly be reinterpreted as providing an estimate of the overall effect of liquidity and liquidity risk.

Robustness, size, and book-to-market. To check the robustness of our results, we consider different specifications and portfolios. First, we consider whether our results are robust to the choice of value weighting versus equal weighting. Table $5 \mathrm{~A}$ reports the results with equal-weighted illiquidity portfolios and equal-weighted market, and Table 5B with value-weighted illiquidity portfolios and value-weighted market. The results and their significance are similar to those of Table 4A. First, $\beta^{\text {net }}$ is borderline significant at a $5 \%$ level in line 1 of Table $5 \mathrm{~A}$, but insignificant at this

\footnotetext{
${ }^{14}$ In another recent paper, Chordia et al. (2001b) find that expected returns in the cross-section are higher for stocks with low variability of liquidity, measured using variables such as trading volume and turnover. They examine the firm-specific variability of liquidity. By contrast, our model and tests suggest that it is the co-movement of firm-specific liquidity with market return and market liquidity that affects expected returns.
} 
Table 5

Illiquidity portfolios: robustness of weighting method

This table reports the estimated coefficients from cross-sectional regressions of the liquidity-adjusted CAPM for 25 illiquidity portfolios using monthly data during 1964-1999. We consider special cases of the relation

$$
E\left(r_{t}^{p}-r_{t}^{f}\right)=\alpha+\kappa E\left(c_{t}^{p}\right)+\lambda^{1} \beta^{1 p}+\lambda^{2} \beta^{2 p}+\lambda^{3} \beta^{3 p}+\lambda^{4} \beta^{4 p}+\lambda \beta^{\text {net }, p},
$$

where $\beta^{\text {net }, p}=\beta^{1 p}+\beta^{2 p}-\beta^{3 p}-\beta^{4 p}$. In some specifications, $\kappa$ is set to be the average monthly turnover. The $t$-statistic, reported in the parentheses, is estimated using a GMM framework that takes into account the pre-estimation of the betas. The $R^{2}$ is obtained in a single cross-sectional regression, and the adjusted $R^{2}$ is reported in parentheses.

\begin{tabular}{|c|c|c|c|c|c|c|c|c|}
\hline & Constant & $E\left(c^{p}\right)$ & $\beta^{1 p}$ & $\beta^{2 p}$ & $\beta^{3 p}$ & $\beta^{4 p}$ & $\beta^{\text {net }, p}$ & $R^{2}$ \\
\hline \multicolumn{9}{|c|}{ Panel A: equal-weighted portfolios, equal-weighted market } \\
\hline \multirow[t]{2}{*}{1} & -0.391 & 0.046 & & & & & 1.115 & 0.825 \\
\hline & $(-0.889)$ & $(-)$ & & & & & $(1.997)$ & $(0.825)$ \\
\hline \multirow[t]{2}{*}{2} & -0.299 & 0.062 & & & & & 0.996 & 0.846 \\
\hline & $(-0.737)$ & $(3.878)$ & & & & & $(4.848)$ & $(0.832)$ \\
\hline \multirow[t]{2}{*}{3} & -0.530 & & 1.374 & & & & & 0.350 \\
\hline & $(-1.082)$ & & $(2.085)$ & & & & & $(0.322)$ \\
\hline \multirow[t]{2}{*}{4} & -0.088 & 0.046 & -2.699 & & & & 3.395 & 0.879 \\
\hline & $(-0.249)$ & $(-)$ & $(-1.441)$ & & & & $(1.782)$ & $(0.873)$ \\
\hline \multirow[t]{2}{*}{5} & 0.105 & 0.008 & -6.392 & & & & 6.800 & 0.901 \\
\hline & $(0.296)$ & $(0.318)$ & $(-2.238)$ & & & & $(2.427)$ & $(0.886)$ \\
\hline \multirow[t]{2}{*}{6} & 0.143 & & -7.115 & & & & 7.467 & 0.900 \\
\hline & $(0.397)$ & & $(-3.623)$ & & & & $(3.871)$ & $(0.891)$ \\
\hline \multirow[t]{2}{*}{7} & -0.132 & 0.046 & 1.568 & -141.416 & 47.823 & -12.784 & & 0.911 \\
\hline & $(-0.633)$ & $(-)$ & $(1.295)$ & $(-1.032)$ & $(0.469)$ & $(-1.553)$ & & $(0.898)$ \\
\hline \multirow[t]{2}{*}{8} & -0.053 & 0.117 & 1.207 & -346.547 & 33.043 & -17.356 & & 0.913 \\
\hline & $(-0.060)$ & $(0.837)$ & $(0.343)$ & $(-0.796)$ & $(0.186)$ & $(-0.981)$ & & $(0.890)$ \\
\hline \multicolumn{9}{|c|}{ Panel B: value-weighted portfolios, value-weighted market } \\
\hline \multirow[t]{2}{*}{1} & -1.938 & 0.034 & & & & & 2.495 & 0.486 \\
\hline & $(-1.203)$ & $(-)$ & & & & & $(1.627)$ & $(0.486)$ \\
\hline \multirow[t]{2}{*}{2} & -2.059 & 0.081 & & & & & 2.556 & 0.642 \\
\hline & $(-1.755)$ & $(2.755)$ & & & & & $(2.107)$ & $(0.609)$ \\
\hline \multirow[t]{2}{*}{3} & 0.700 & & 0.062 & & & & & 0.000 \\
\hline & $(0.272)$ & & $(0.025)$ & & & & & $(-0.043)$ \\
\hline \multirow[t]{2}{*}{4} & -1.536 & 0.034 & -6.070 & & & & 8.099 & 0.754 \\
\hline & $(-2.033)$ & $(-)$ & $(-1.540)$ & & & & $(2.040)$ & $(0.743)$ \\
\hline \multirow[t]{2}{*}{5} & -0.583 & -0.076 & -16.226 & & & & 17.333 & 0.841 \\
\hline & $(-0.718)$ & $(-0.902)$ & $(-2.978)$ & & & & (3.543) & $(0.819)$ \\
\hline \multirow[t]{2}{*}{6} & -1.241 & & -9.210 & & & & 10.954 & 0.800 \\
\hline & $(-1.271)$ & & $(-2.733)$ & & & & $(3.183)$ & $(0.781)$ \\
\hline \multirow[t]{2}{*}{7} & -0.301 & 0.034 & 0.363 & -4494.924 & -370.840 & -26.044 & & 0.850 \\
\hline & $(-0.285)$ & $(-)$ & $(0.268)$ & $(-1.060)$ & $(-0.806)$ & $(-1.366)$ & & $(0.828)$ \\
\hline \multirow[t]{2}{*}{8} & 0.039 & -0.056 & 0.015 & -116.450 & -405.451 & -13.135 & & 0.865 \\
\hline & $(0.031)$ & $(-0.140)$ & $(0.007)$ & $(-0.010)$ & $(-0.413)$ & $(-0.270)$ & & $(0.829)$ \\
\hline
\end{tabular}


level in Table 5B. In both tables, the liquidity-adjusted CAPM has a higher R-square than the standard CAPM. In particular, with value-weighted portfolios in Table 5B, the standard CAPM has an R-square of $0.0 \%$, whereas the liquidity-adjusted CAPM has an R-square of $48.6 \%$. There is further evidence that liquidity risk matters over and above liquidity level and market risk. In particular, $\beta^{\text {net }}$ is significant in line 5 of Table 5A, and in all of lines 4-6 in Table 5B. (Also, $\beta^{\text {net }}$ is significant in line 6 of Table $5 \mathrm{~A}$, but this line is not relevant since the coefficient on $E\left(c^{p}\right)$ has the correct sign in line 5.)

As a further robustness check, we re-estimate our model with size-based portfolios and portfolios sorted first into five book-to-market quintiles and then into five size quintiles within the book-to-market groups.

Small-sized stocks are illiquid (in absolute terms as measured by $E(c)$ ) and also have high liquidity risk (as measured by the three betas $\beta^{2 p}, \beta^{3 p}$, and $\beta^{4 p}$ ). Table $6 \mathrm{~A}$ shows that the cross-sectional regressions have coefficients that are similar to our earlier results, but the statistical significance is reduced. The coefficient of $\beta^{\text {net }}$ is estimated to be positive and the liquidity-adjusted CAPM still has a higher $R^{2}$ than the standard CAPM. Fig. 4 shows graphically the fit for size portfolios of the standard CAPM, and the liquidity-adjusted CAPM, with constrained and unconstrained risk premia. We see that the liquidity adjustment improves the fit, particularly for the smaller size portfolios.

Table 6B and Fig. 5 show the model's fit of the B/M-by-size portfolios. We recover the well-known result (see Fama and French, 1992, 1993) that CAPM does relatively poorly for $\mathrm{B} / \mathrm{M}$-by-size portfolios (adjusted $R^{2}=22.9 \%$ ) since market beta is relatively "flat" across these portfolios. The liquidity-adjusted CAPM in line 1 provides a moderate improvement in the fit (adjusted $R^{2}=40.6 \%$ ) whereas the model with unconstrained risk premia produces a significant improvement in the fit (adjusted $R^{2}=73.3 \%$ ). It should be noted, however, that the unconstrained specification may be "over fitted" in the sense that some of the risk premia estimated have an incorrect sign and they are all insignificant. The negative coefficient on $\beta^{\text {net }}$ in line 5 suggests that the model is misspecified for these portfolios.

To further consider the model's ability to explain the size and book-to-market effects, we run our regressions while controlling for size and book-to-market (Table 7). We do this both for illiquidity portfolios (Panel A) and for B/M-by-size portfolios (Panel B). The results with illiquidity portfolios are similar to the earlier results, although the standard errors increase because of the additional variables. The coefficient on $\beta^{\text {net }}$ is significant in the liquidity-adjusted CAPM of line 1 . The coefficient on size is always insignificant and the coefficient on book-to-market is insignificant in all specifications except line 2. (Including volatility does not change the results, and volatility is not significant. These results are not reported.) With B/M-by-size portfolios (Table 7B), the model performs poorly. Indeed, the coefficient on $\beta^{\text {net }}$ is negative, although insignificant, and the coefficient on $\mathrm{B} / \mathrm{M}$ is significant in most specifications. To summarize, the results with illiquidity portfolios suggest that liquidity risk matters while controlling for book to market, while the results with $\mathrm{B} / \mathrm{M}$-by-size portfolios suggest that liquidity risk does not explain the 
Table 6

Size and B/M-by-size portfolios

This table reports the estimated coefficients from cross-sectional regressions of the liquidity-adjusted CAPM for 25 value-weighted size and B/M-by-size portfolios using monthly data during 1964-1999 with an equal-weighted market portfolio. We consider special cases of the relation

$$
E\left(r_{t}^{p}-r_{t}^{f}\right)=\alpha+\kappa E\left(c_{t}^{p}\right)+\lambda^{1} \beta^{1 p}+\lambda^{2} \beta^{2 p}+\lambda^{3} \beta^{3 p}+\lambda^{4} \beta^{4 p}+\lambda \beta^{\text {net }, p},
$$

where $\beta^{\text {net }, p}=\beta^{1 p}+\beta^{2 p}-\beta^{3 p}-\beta^{4 p}$. In some specifications, $\kappa$ is set to be the average monthly turnover. The $t$-statistic, reported in the parentheses, is estimated using a GMM framework that takes into account the pre-estimation of the betas. The $R^{2}$ is obtained in a single cross-sectional regression, and the adjusted $R^{2}$ is reported in parentheses.

\begin{tabular}{|c|c|c|c|c|c|c|c|c|}
\hline & Constant & $E\left(c^{p}\right)$ & $\beta^{1 p}$ & $\beta^{2 p}$ & $\beta^{3 p}$ & $\beta^{4 p}$ & $\beta^{\text {net }, p}$ & $R^{2}$ \\
\hline \multicolumn{9}{|c|}{ Panel A: size portfolios } \\
\hline \multirow[t]{2}{*}{1} & -0.087 & 0.047 & & & & & 0.865 & 0.910 \\
\hline & $(-0.274)$ & $(-)$ & & & & & $(1.864)$ & $(0.910)$ \\
\hline \multirow[t]{2}{*}{2} & -0.059 & 0.056 & & & & & 0.823 & 0.912 \\
\hline & $(-0.201)$ & $(2.139)$ & & & & & $(1.768)$ & $(0.904)$ \\
\hline \multirow[t]{2}{*}{3} & -0.265 & & 1.144 & & & & & 0.757 \\
\hline & $(-0.789)$ & & $(2.270)$ & & & & & $(0.747)$ \\
\hline \multirow[t]{2}{*}{4} & -0.043 & 0.047 & -0.770 & & & & 1.562 & 0.912 \\
\hline & $(-0.151)$ & $(-)$ & $(-0.323)$ & & & & $(0.685)$ & $(0.908)$ \\
\hline \multirow[t]{2}{*}{5} & -0.055 & 0.054 & -0.168 & & & & 0.984 & 0.912 \\
\hline & $(-0.186)$ & $(1.180)$ & $(-0.050)$ & & & & $(0.266)$ & $(0.900)$ \\
\hline \multirow[t]{2}{*}{6} & 0.032 & & -4.633 & & & & 5.278 & 0.902 \\
\hline & $(0.112)$ & & $(-1.899)$ & & & & $(2.104)$ & $(0.893)$ \\
\hline \multirow[t]{2}{*}{7} & -0.073 & 0.047 & 0.887 & 27.387 & 1.741 & 0.038 & & 0.913 \\
\hline & $(-0.122)$ & $(-)$ & $(0.304)$ & $(0.342)$ & $(0.009)$ & $(0.006)$ & & $(0.901)$ \\
\hline \multirow[t]{2}{*}{8} & 0.224 & -0.408 & -0.079 & 742.841 & -42.800 & 7.933 & & 0.929 \\
\hline & $(0.552)$ & $(-1.206)$ & $(-0.047)$ & $(1.157)$ & $(-0.845)$ & $(0.691)$ & & $(0.911)$ \\
\hline \multicolumn{9}{|c|}{ Panel B: B/M-by-size properties } \\
\hline \multirow[t]{2}{*}{1} & 0.200 & 0.045 & & & & & 0.582 & 0.406 \\
\hline & $(0.680)$ & $(-)$ & & & & & $(1.197)$ & $(0.406)$ \\
\hline \multirow[t]{2}{*}{2} & 0.453 & 0.167 & & & & & 0.182 & 0.541 \\
\hline & $(1.657)$ & $(3.452)$ & & & & & $(0.377)$ & $(0.499)$ \\
\hline \multirow[t]{2}{*}{3} & 0.109 & & 0.748 & & & & & 0.262 \\
\hline & $(0.348)$ & & $(1.406)$ & & & & & $(0.229)$ \\
\hline \multirow[t]{2}{*}{4} & 0.529 & 0.045 & -8.289 & & & & 8.275 & 0.502 \\
\hline & $(1.665)$ & $(-)$ & $(-2.013)$ & & & & $(2.198)$ & $(0.481)$ \\
\hline \multirow[t]{2}{*}{5} & 0.187 & 0.387 & 18.229 & & & & -17.458 & 0.571 \\
\hline & $(0.626)$ & $(3.061)$ & (2.344) & & & & $(-2.265)$ & $(0.510)$ \\
\hline \multirow[t]{2}{*}{6} & 0.574 & & -11.787 & & & & 11.671 & 0.483 \\
\hline & (1.959) & & $(-3.102)$ & & & & $(2.902)$ & $(0.436)$ \\
\hline \multirow[t]{2}{*}{7} & -0.425 & 0.045 & 4.606 & 203.397 & 198.027 & -3.330 & & 0.788 \\
\hline & $(-0.254)$ & $(-)$ & $(0.483)$ & $(0.200)$ & $(0.526)$ & $(-0.049)$ & & $(0.758)$ \\
\hline \multirow[t]{2}{*}{8} & -0.395 & -0.031 & 4.545 & 397.770 & 195.128 & 0.380 & & 0.789 \\
\hline & $(-0.638)$ & $(-0.028)$ & $(1.722)$ & $(0.115)$ & (1.612) & $(0.004)$ & & $(0.733)$ \\
\hline
\end{tabular}



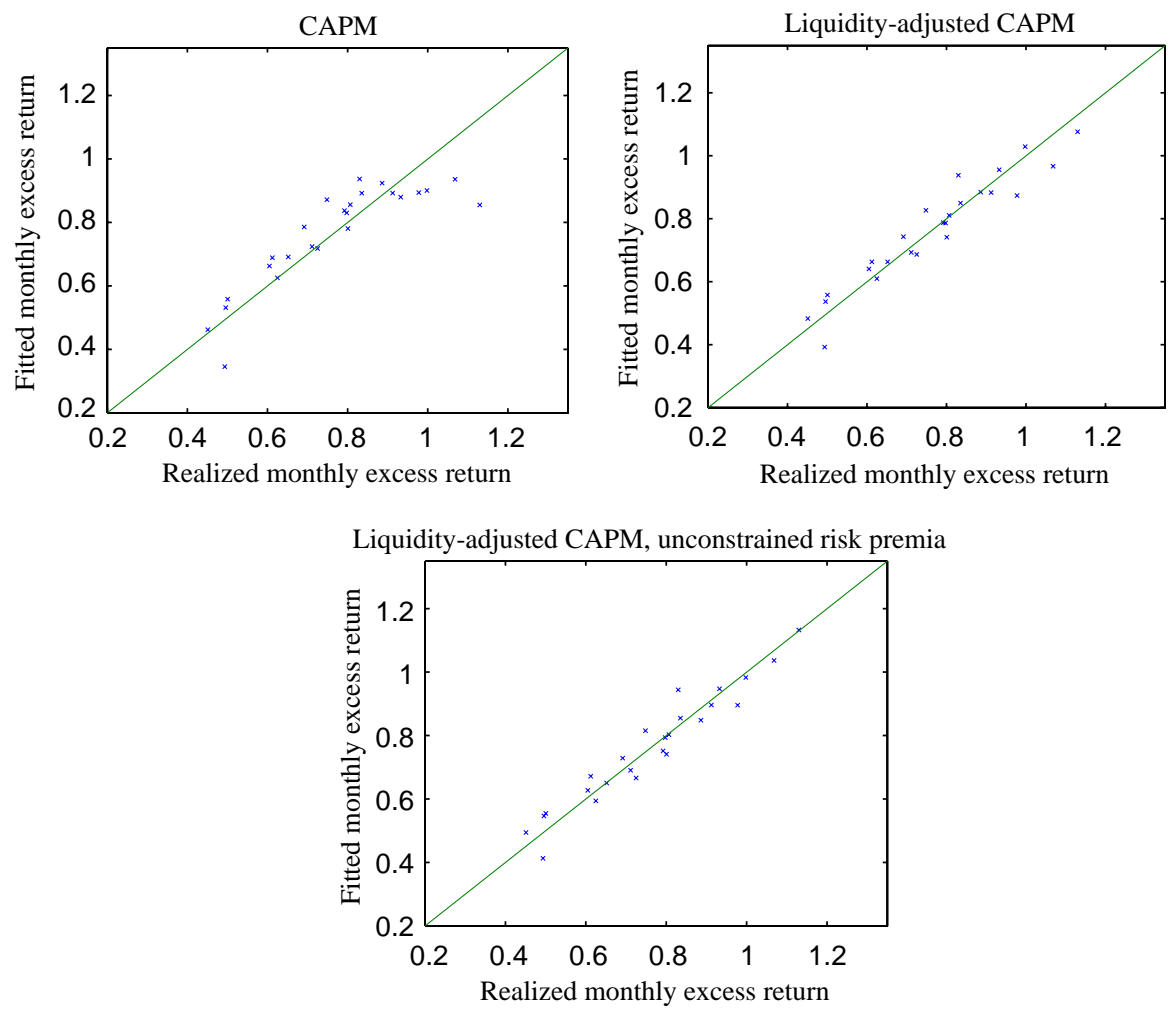

Fig. 4. Size portfolios: the top left panel shows the fitted CAPM returns vs. realized returns using monthly data 1964-1999 for value-weighted size portfolios. The top right panel shows the same for the liquidityadjusted CAPM, and the lower panel shows the relation for the liquidity-adjusted CAPM with unconstrained risk premia.

book-to-market effect. (Pastor and Stambaugh, 2003 reach a similar conclusion.) Hence, our simple model fails to explain the entire investment universe.

Specification tests. We perform several specification tests of the liquidity-adjusted CAPM. First, we note that we fail to reject at conventional levels the model-implied restriction that $\alpha=0$ in the liquidity-adjusted CAPM (lines 1-2 and 4-8 of Table 4), whereas this restriction is rejected for the standard CAPM (at a 10\% level in line 3 Table 4A, and at a 5\% level in Table 4B). Second, in context of the model with unrestricted risk premia in line 8 of Table 4 , a Wald test fails to reject the five modelimplied restrictions $\lambda^{1}=\lambda^{2}=-\lambda^{3}=-\lambda^{4}, \alpha=0$, and $\kappa=k$, where $k$ is the calibrated value. The $p$-value is $47 \%$ in Table $4 \mathrm{~A}$ and $28 \%$ in Table $4 \mathrm{~B}$. The CAPM restrictions $\lambda^{2}=\lambda^{3}=\lambda^{4}=0, \alpha=0$, and $\kappa=0$ have $p$-values of $15 \%$ and $8.7 \%$, respectively. The CAPM is rejected in lines 5 and 6 since $\beta^{\text {net }}$ is significant.

Another testable restriction implied by the model is that the risk premium equals the expected net return on the market in excess of the risk-free rate. The point 

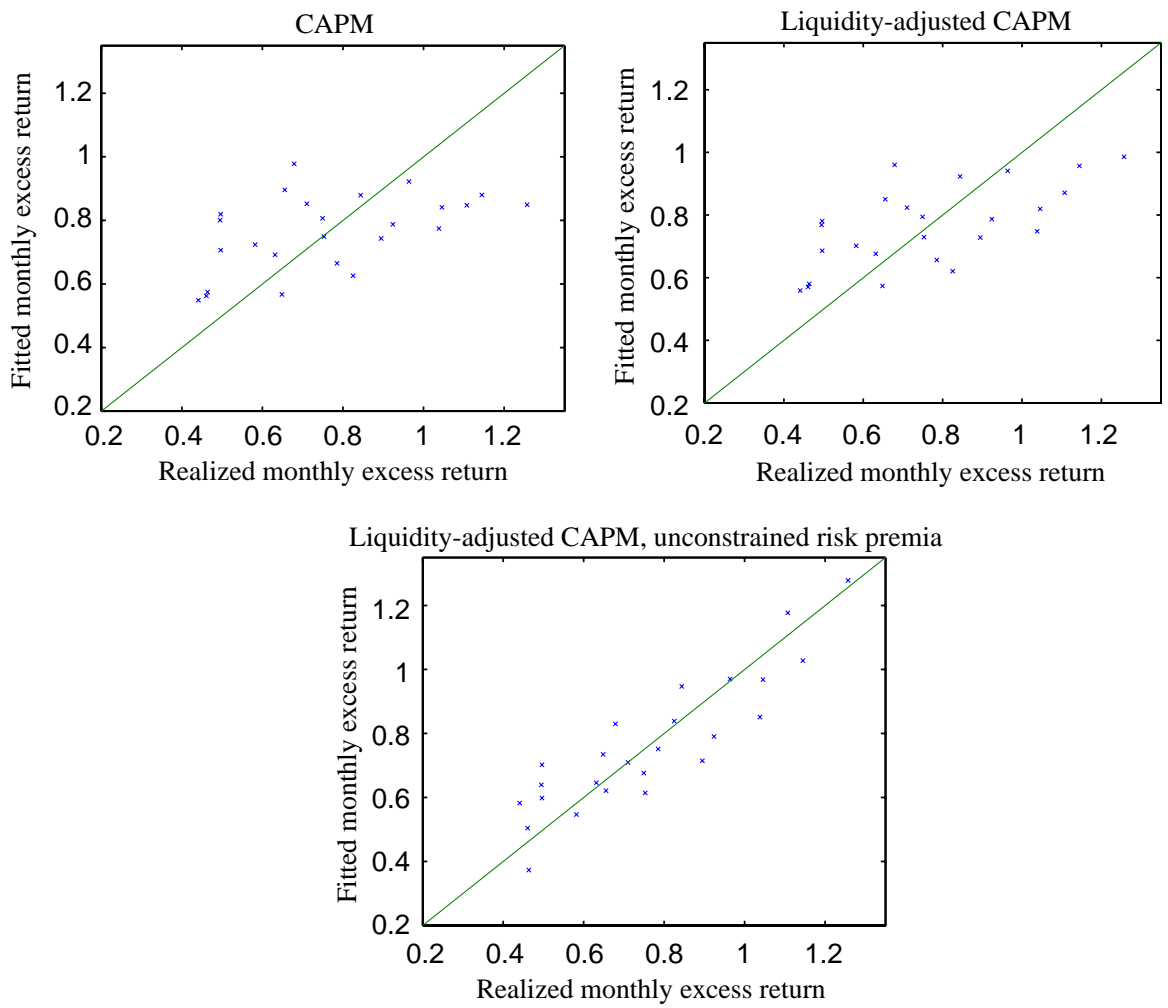

Fig. 5. Book-to-market by size portfolios: the top left panel shows the fitted CAPM returns vs. realized returns using monthly data 1964-1999 for value-weighted BM-size portfolios. The top right panel shows the same for the liquidity-adjusted CAPM, and the lower panel shows the relation for the liquidityadjusted CAPM with unconstrained risk premia.

estimate of the risk premium, $\lambda$, is larger than the sample average of the excess return of the market net of transaction costs, $E\left(r_{t}^{M}-r_{t}^{f}-\kappa c_{t}^{M}\right)$, and the $p$-value is $6.6 \%$ in regression 1 of Table $4 \mathrm{~A}$ and $7.3 \%$ in Table 4B. In comparison, the test that the standard CAPM risk premium equals the $E\left(r_{t}^{M}-r_{t}^{f}\right)$ has $p$-values of $1.2 \%$ and $0.8 \%$, respectively.

Lastly, we test that the linear model has zero average pricing error for all of the portfolios, a stringent test since it requires that the model is pricing all portfolios correctly. With illiquidity portfolios, the $p$-values for the liquidity-adjusted CAPM in regressions 1,5 , and 8 are, respectively, $8.5 \%, 9.9 \%$, and $6.8 \%$ using a GMM test (as in Cochrane, 2001, p. 241), which is similar to the cross-sectional regression test of Shanken (1985). In comparison, the standard CAPM has a $p$-value of $0.5 \%$. With $\sigma$ (illiquidity) portfolios the GMM $p$-values for the liquidity-adjusted CAPM are, respectively, $16 \%, 42 \%$, and $65 \%$, and the $p$-value for the standard CAPM is $6.6 \%$. The specification tests for size portfolios are similar. This confirms the visual 
Table 7

Controlling for size and book-to-market

This table reports the estimated coefficients from cross-sectional regressions of the liquidity-adjusted CAPM for 25 value-weighted size and B/M-by-size portfolios using monthly data during 1964-1999 with an equal-weighted market portfolio. We consider special cases of the relation

$$
E\left(r_{t}^{p}-r_{t}^{f}\right)=\alpha+\kappa E\left(c_{t}^{p}\right)+\lambda^{1} \beta^{1 p}+\lambda^{2} \beta^{2 p}+\lambda^{3} \beta^{3 p}+\lambda^{4} \beta^{4 p}+\lambda \beta^{\text {net } p}+\lambda^{5} \ln \left(\operatorname{size}^{p}\right)+\lambda^{6} B M^{p},
$$

where $\beta^{\text {net, } p}=\beta^{1 p}+\beta^{2 p}-\beta^{3 p}-\beta^{4 p}, \ln \left(\operatorname{size}^{p}\right)$ is the time-series average of the natural log of the ratio of the portfolio's market capitalization at the beginning of the month to the total market capitalization, and $\mathrm{BM}^{p}$ is the time-series average of the average monthly book-to-market of the stocks constituting the portfolio. In some specifications, $\kappa$ is set to be the average monthly turnover. The $t$-statistic, reported in the parentheses, is estimated using a GMM framework that takes into account the pre-estimation of betas The $R^{2}$ is obtained in a single cross-sectional regression, and the adjusted $R^{2}$ is reported in parentheses.

\begin{tabular}{|c|c|c|c|c|c|c|c|c|c|c|}
\hline & Constant & $E\left(c^{p}\right)$ & $\beta^{1 p}$ & $\beta^{2 p}$ & $\beta^{3 p}$ & $\beta^{4 p}$ & $\beta^{\text {net }, p}$ & $\ln \left(\operatorname{size}^{p}\right)$ & $\mathrm{B} / \mathrm{M}$ & $R^{2}$ \\
\hline \multicolumn{11}{|c|}{ Panel A: liquidity portfolios } \\
\hline 1 & $\begin{array}{l}-1.358 \\
(-1.843)\end{array}$ & $\begin{array}{l}0.034 \\
(-)\end{array}$ & & & & & $\begin{array}{l}2.158 \\
(2.114)\end{array}$ & $\begin{array}{l}0.142 \\
(1.247)\end{array}$ & $\begin{array}{c}1.076 \\
(1.871)\end{array}$ & $\begin{array}{c}0.865 \\
(0.852)\end{array}$ \\
\hline 2 & $\begin{array}{l}-1.286 \\
(-1.501)\end{array}$ & $\begin{array}{l}0.028 \\
(1.129)\end{array}$ & & & & & $\begin{array}{l}1.970 \\
(1.869)\end{array}$ & $\begin{array}{l}0.129 \\
(0.950)\end{array}$ & $\begin{array}{c}1.120 \\
(2.215)\end{array}$ & $\begin{array}{c}0.865 \\
(0.838)\end{array}$ \\
\hline 3 & $\begin{array}{l}-0.818 \\
(-0.837)\end{array}$ & & $\begin{array}{l}0.798 \\
(0.651)\end{array}$ & & & & & $\begin{array}{l}0.043 \\
(0.302)\end{array}$ & $\begin{array}{c}1.350 \\
(1.724)\end{array}$ & $\begin{array}{c}0.850 \\
(0.829)\end{array}$ \\
\hline 4 & $\begin{array}{l}-1.273 \\
(-1.459)\end{array}$ & $\begin{array}{l}0.034 \\
(-)\end{array}$ & $\begin{array}{l}-3.740 \\
(-0.576)\end{array}$ & & & & $\begin{array}{l}6.145 \\
(0.891)\end{array}$ & $\begin{array}{l}0.155 \\
(1.054)\end{array}$ & $\begin{array}{c}0.679 \\
(0.814)\end{array}$ & $\begin{array}{c}0.869 \\
(0.850)\end{array}$ \\
\hline 5 & $\begin{array}{l}-0.441 \\
(-0.613)\end{array}$ & $\begin{array}{l}-0.018 \\
(-0.227)\end{array}$ & $\begin{array}{l}-12.278 \\
(-1.292)\end{array}$ & & & & $\begin{array}{l}13.565 \\
(1.453)\end{array}$ & $\begin{array}{l}0.068 \\
(0.871)\end{array}$ & $\begin{array}{c}0.159 \\
(0.229)\end{array}$ & $\begin{array}{c}0.882 \\
(0.850)\end{array}$ \\
\hline 6 & $\begin{array}{l}-0.730 \\
(-0.939)\end{array}$ & & $\begin{array}{l}-9.313 \\
(-1.884)\end{array}$ & & & & $\begin{array}{l}10.988 \\
(2.106)\end{array}$ & $\begin{array}{l}0.098 \\
(0.788)\end{array}$ & $\begin{array}{c}0.339 \\
(0.598)\end{array}$ & $\begin{array}{c}0.880 \\
(0.856)\end{array}$ \\
\hline 7 & $\begin{array}{l}-0.491 \\
(-0.369)\end{array}$ & $\begin{array}{l}0.034 \\
(-)\end{array}$ & $\begin{array}{l}1.253 \\
(0.714)\end{array}$ & $\begin{array}{l}-124.221 \\
(-0.818)\end{array}$ & $\begin{array}{c}-18.359 \\
(-0.180)\end{array}$ & $\begin{array}{l}-16.421 \\
(-1.230)\end{array}$ & & $\begin{array}{l}0.078 \\
(0.313)\end{array}$ & $\begin{array}{c}0.205 \\
(0.208)\end{array}$ & $\begin{array}{c}0.884 \\
(0.853)\end{array}$ \\
\hline 8 & $\begin{array}{l}-0.557 \\
(-0.912)\end{array}$ & $\begin{array}{l}0.059 \\
(0.298)\end{array}$ & $\begin{array}{l}1.300 \\
(2.043)\end{array}$ & $\begin{array}{l}-183.466 \\
(-0.325)\end{array}$ & $\begin{array}{l}-19.865 \\
(-0.208)\end{array}$ & $\begin{array}{l}-17.238 \\
(-0.922)\end{array}$ & & $\begin{array}{l}0.087 \\
(0.773)\end{array}$ & $\begin{array}{c}0.253 \\
(0.376)\end{array}$ & $\begin{array}{c}0.884 \\
(0.836)\end{array}$ \\
\hline \multicolumn{11}{|c|}{ Panel B: B/M-by-size portfolios } \\
\hline 1 & $\begin{array}{l}0.310 \\
(1.040)\end{array}$ & $\begin{array}{l}0.045 \\
(-)\end{array}$ & & & & & $\begin{array}{l}-0.199 \\
(-0.345)\end{array}$ & $\begin{array}{l}-0.084 \\
(-1.415)\end{array}$ & $\begin{array}{c}0.251 \\
(2.892)\end{array}$ & $\begin{array}{c}0.924 \\
(0.917)\end{array}$ \\
\hline 2 & $\begin{array}{l}0.317 \\
(1.206)\end{array}$ & $\begin{array}{l}0.035 \\
(0.684)\end{array}$ & & & & & $\begin{array}{l}-0.236 \\
(-0.311)\end{array}$ & $\begin{array}{l}-0.091 \\
(-1.176)\end{array}$ & $\begin{array}{c}0.250 \\
(2.905)\end{array}$ & $\begin{array}{c}0.925 \\
(0.910)\end{array}$ \\
\hline 3 & $\begin{array}{l}0.365 \\
(1.177)\end{array}$ & & $\begin{array}{l}-0.403 \\
(-0.516)\end{array}$ & & & & & $\begin{array}{l}-0.119 \\
(-2.155)\end{array}$ & $\begin{array}{c}0.246 \\
(2.749)\end{array}$ & $\begin{array}{c}0.920 \\
(0.909)\end{array}$ \\
\hline 4 & $\begin{array}{l}0.311 \\
(1.170)\end{array}$ & $\begin{array}{l}0.045 \\
(-)\end{array}$ & $\begin{array}{l}0.484 \\
(0.155)\end{array}$ & & & & $\begin{array}{l}-0.696 \\
(-0.262)\end{array}$ & $\begin{array}{l}-0.089 \\
(-1.598)\end{array}$ & $\begin{array}{c}0.249 \\
(2.960)\end{array}$ & $\begin{array}{c}0.924 \\
(0.913)\end{array}$ \\
\hline 5 & $\begin{array}{l}0.340 \\
(1.083)\end{array}$ & $\begin{array}{l}-0.003 \\
(-0.039)\end{array}$ & $\begin{array}{l}-3.145 \\
(-0.894)\end{array}$ & & & & $\begin{array}{l}2.850 \\
(0.846)\end{array}$ & $\begin{array}{l}-0.087 \\
(-1.224)\end{array}$ & $\begin{array}{c}0.259 \\
(3.108)\end{array}$ & $\begin{array}{c}0.925 \\
(0.906)\end{array}$ \\
\hline 6 & $\begin{array}{l}0.338 \\
(1.003)\end{array}$ & & $\begin{array}{l}-2.930 \\
(-1.366)\end{array}$ & & & & $\begin{array}{l}2.639 \\
(0.613)\end{array}$ & $\begin{array}{l}-0.087 \\
(-1.065)\end{array}$ & $\begin{array}{c}0.259 \\
(3.314)\end{array}$ & $\begin{array}{c}0.925 \\
(0.910)\end{array}$ \\
\hline 7 & $\begin{array}{l}0.237 \\
(1.483)\end{array}$ & $\begin{array}{l}0.045 \\
(-)\end{array}$ & $\begin{array}{l}0.490 \\
(0.284)\end{array}$ & $\begin{array}{l}-286.927 \\
(-1.063)\end{array}$ & $\begin{array}{l}38.480 \\
(0.615)\end{array}$ & $\begin{array}{l}-14.711 \\
(-1.069)\end{array}$ & & $\begin{array}{l}-0.095 \\
(-1.613)\end{array}$ & $\begin{array}{c}0.226 \\
(2.868)\end{array}$ & $\begin{array}{c}0.932 \\
(0.915)\end{array}$ \\
\hline 8 & $\begin{array}{l}0.171 \\
(0.249)\end{array}$ & $\begin{array}{l}0.284 \\
(0.308)\end{array}$ & $\begin{array}{l}0.529 \\
(0.232)\end{array}$ & $\begin{array}{l}-916.982 \\
(-0.344)\end{array}$ & $\begin{array}{l}42.353 \\
(0.181)\end{array}$ & $\begin{array}{l}-26.730 \\
(-0.391)\end{array}$ & & $\begin{array}{l}-0.100 \\
(-0.735)\end{array}$ & $\begin{array}{c}0.233 \\
(0.746)\end{array}$ & $\begin{array}{c}0.937 \\
(0.911)\end{array}$ \\
\hline
\end{tabular}


evidence from Figs. 2-4 that the liquidity-adjusted CAPM has a better fit than the standard CAPM for these portfolios.

With B/M-by-size portfolios, the Wald test of the liquidity-adjusted CAPM has a $p$-value of $47 \%$ and the test of zero pricing errors for regressions 1,5 , and 8 are, respectively, $15.7 \%, 38 \%$, and $85 \%$. The standard CAPM has a $p$-value of $23 \%$ for the Wald test and $3.2 \%$ for the test of zero pricing errors. The failure to reject the liquidity-adjusted CAPM using $B / M$-by-size portfolios may be due to low power since, as discussed above, the model fit is not good for these portfolios.

\section{Conclusion}

This paper derives a simple model of liquidity risk. The model shows that the CAPM applies for returns net of illiquidity costs. This implies that investors should worry about a security's performance and tradability both in market downturns and when liquidity "dries up." Said differently, the required return of a security $i$ is increasing in the covariance between its illiquidity and the market illiquidity, $\operatorname{cov}_{t}\left(c_{t+1}^{i}, c_{t+1}^{M}\right)$, decreasing in the covariance between the security's return and the market illiquidity, $\operatorname{cov}_{t}\left(r_{t+1}^{i}, c_{t+1}^{M}\right)$, and decreasing in the covariance between its illiquidity and market returns, $\operatorname{cov}_{t}\left(c_{t+1}^{i}, r_{t+1}^{M}\right)$. The model further shows that positive shocks to illiquidity, if persistent, are associated with a low contemporaneous returns and high predicted future returns.

Hence, the model gives an integrated view of the existing empirical evidence related to liquidity and liquidity risk, and it generates new testable predictions. We find that the liquidity-adjusted CAPM explains the data better than the standard CAPM, while still exploiting the same degrees of freedom. Further, we find weak evidence that liquidity risk is important over and above the effects of market risk and the level of liquidity. The model has a reasonably good fit for portfolios sorted by liquidity, liquidity variation, and size, but it fails to explain the book-to-market effect.

The model provides a framework in which we can study the economic significance of liquidity risk. We find that liquidity risk explains about $1.1 \%$ of cross-sectional returns when the effect of average liquidity is calibrated to the typical holding period in the data and the model restriction of a single risk premium is imposed. About $80 \%$ of this effect is due to the liquidity sensitivity to the market return, $\operatorname{cov}_{t}\left(c_{t+1}^{i}, r_{t+1}^{M}\right)$, an effect not previously studied in the literature. Freeing up risk premia leads to larger estimates of the liquidity risk premium, but these results are estimated imprecisely because of collinearity between liquidity and liquidity risk.

While the model gives clear predictions that seem to have some bearing in the data, it is obviously simplistic. The model and the empirical results are suggestive of further theoretical and empirical work. In particular, it would be of interest to explain the time-variation in liquidity, and our finding of "flight to liquidity" namely that stocks that are illiquid in absolute terms also are more liquidity risky in the sense of having high values of all three liquidity betas. Another interesting topic is the determination of liquidity premia in a general equilibrium with liquidity risk and 
endogenous holdings periods. We note that if investors live several periods, but their probability of living more than one period approaches zero, then our equilibrium economy is approached, assuming continuity. Hence, our effects would also be present in the more general economy, although endogenous holding periods may imply a smaller effect of liquidity risk (as in Constantinides, 1986). The effect of liquidity risk is strengthened, however, if investors have important reasons to trade frequently. Such reasons include return predictability and wealth shocks (as considered in the context of liquidity by Lynch and Tan, 2003), differences of opinions (e.g., Harris and Raviv, 1993), asymmetric information (e.g., He and Wang, 1995), institutional effects (e.g., Allen, 2001), taxes (e.g., Constantinides, 1983), etc. It would be interesting to determine the equilibrium impact of liquidity risk in light of such trading motives.

\section{Appendix}

\section{Proof of Proposition 1}

We first solve the investment problem of any investor $n$ at time $t$. We assume, and later confirm, that the price at time $t+1$ is normally distributed conditional on time$t$ information. Hence, the investor's problem is to choose optimally the number of shares, $y^{n}=\left(y^{n, 1}, \ldots, y^{n, I}\right)$, to purchase according to

$$
\max _{y^{n} \in \mathbb{R}_{+}^{I}}\left(E_{t}\left(W_{t+1}^{n}\right)-\frac{1}{2} A^{n} \operatorname{var}_{t}\left(W_{t+1}^{n}\right)\right) \text {, }
$$

where

$$
W_{t+1}^{n}=\left(P_{t+1}+D_{t+1}-C_{t+1}\right)^{\top} y^{n}+r^{f}\left(e_{t}^{n}-P_{t}^{\top} y^{n}\right)
$$

and $e_{t}^{n}$ is this agent's endowment. If we disregard the no-short-sale constraint, the solution is

$$
y^{n}=\frac{1}{A^{n}}\left(\operatorname{var}_{t}\left(P_{t+1}+D_{t+1}-C_{t+1}\right)\right)^{-1}\left(E_{t}\left(P_{t+1}+D_{t+1}-C_{t+1}\right)-r^{f} P_{t}\right) .
$$

We shortly verify that, in equilibrium, this solution does not entail short-selling. In equilibrium, $\sum_{n} y^{n}=S$, where $S=\left(S^{1}, \ldots, S^{I}\right)$ is the total supply of shares. This implies the equilibrium condition that

$$
P_{t}=\frac{1}{r^{f}}\left[E_{t}\left(P_{t+1}+D_{t+1}-C_{t+1}\right)-A \operatorname{var}_{t}\left(P_{t+1}+D_{t+1}-C_{t+1}\right) S\right],
$$

where $A=\left(\sum_{n} 1 / A^{n}\right)^{-1}$. The unique stationary linear equilibrium is

$$
P_{t}=\Upsilon+\frac{\rho^{D}}{r^{f}-\rho^{D}} D_{t}-\frac{\rho^{C}}{r^{f}-\rho^{C}} C_{t},
$$


where

$$
\begin{aligned}
\Upsilon= & \frac{1}{r^{f}-1}\left(\frac{r^{f}\left(1-\rho^{D}\right)}{r^{f}-\rho^{D}} \bar{D}-\frac{r^{f}\left(1-\rho^{C}\right)}{r^{f}-\rho^{C}} \bar{C}\right. \\
& \left.-A \operatorname{var}\left[\frac{r^{f}}{r^{f}-\rho^{D}} \varepsilon_{t}-\frac{r^{f}}{r^{f}-\rho^{C}} \eta_{t}\right] S\right) .
\end{aligned}
$$

With this price, conditional expected net returns are normally distributed, and any investor $n$ holds a fraction $A / A^{n}>0$ of the market portfolio $S>0$ so he is not shortselling any securities. Therefore, our assumptions are satisfied in equilibrium.

Finally, since investors have mean-variance preferences, the conditional CAPM holds for net returns. See, for instance, Huang and Litzenberger (1988). Rewriting in terms of net returns yields the result stated in the proposition.

\section{Proof of Proposition 2}

The conditional expected return on a portfolio $q$ is computed using (5):

$$
\begin{aligned}
E_{t}\left(r_{t+1}^{q}\right) & =E_{t}\left(\frac{P_{t+1}^{q}+D_{t+1}^{q}}{P_{t}^{q}}\right) \\
& =\frac{E_{t}\left(Y^{q}+\frac{r^{f}}{r^{f}-\rho^{D}} D_{t+1}^{q}-\frac{\rho^{C}}{r^{f}-\rho^{C}} C_{t+1}^{q}\right)}{\Upsilon^{q}+\frac{\rho^{D}}{r^{f}-\rho^{D}} D_{t}^{q}-\frac{\rho^{C}}{r^{f}-\rho^{C}} C_{t}^{q}},
\end{aligned}
$$

so we have

$$
\begin{aligned}
& \frac{\partial}{\partial C_{t}^{q}} E_{t}\left(r_{t+1}^{q}-r^{f}\right) \\
& \quad \frac{1}{\left(P_{t}^{q}\right)^{2}}\left(-\frac{\left(\rho^{C}\right)^{2}}{r^{f}-\rho^{C}} P_{t}^{q}+\frac{\rho^{C}}{r^{f}-\rho^{C}} E_{t}\left(P_{t+1}^{q}+D_{t+1}^{q}\right)\right) .
\end{aligned}
$$

This partial derivative is greater than zero under the conditions given in the proposition.

\section{Proof of Proposition 3}

The conditional covariance between illiquidity and return for a portfolio $q$ is

$$
\begin{aligned}
\operatorname{cov}_{t}\left(c_{t+1}^{q}, r_{t+1}^{q}\right) & =\frac{1}{\left(P_{t}^{q}\right)^{2}} \operatorname{cov}_{t}\left(C_{t+1}^{q}, P_{t+1}^{q}+D_{t+1}^{q}\right) \\
& =\frac{1}{\left(P_{t}^{q}\right)^{2}} \operatorname{cov}_{t}\left(C_{t+1}^{q}, \frac{r^{f}}{r^{f}-\rho^{D}} D_{t+1}^{q}-\frac{\rho^{C}}{r^{f}-\rho^{C}} C_{t+1}^{q}\right) \\
& =\frac{1}{\left(P_{t}^{q}\right)^{2}}\left(\frac{r^{f}}{r^{f}-\rho^{D}} q^{\top} \Sigma^{C D} q-\frac{\rho^{C}}{r^{f}-\rho^{C}} q^{\top} \Sigma^{C} q\right),
\end{aligned}
$$

which yields the proposition. 


\section{References}

Allen, F., 2001. Do financial institutions matter? Journal of Finance 56, 1165-1175.

Amihud, Y., 2002. Illiquidity and stock returns: cross-section and time-series effects. Journal of Financial Markets 5, 31-56.

Amihud, Y., Mendelson, H., 1986. Asset pricing and the bid-ask spread. Journal of Financial Economics $17,223-249$.

Amihud, Y., Mendelson, H., 1989. The effect of beta, bid-ask spread, residual risk and size on stock returns. Journal of Finance 44, 479-486.

Amihud, Y., Mendelson, H., Wood, R., 1990. Liquidity and the 1987 stock market crash. Journal of Portfolio Management, 65-69.

Ang, A., Chen, J., 2002. Asymmetric correlations of equity portfolios. Journal of Financial Economics 63, 443-494.

Bekaert, G., Harvey, C.R., Lundblad, C., 2003. Liquidity and Expected Returns: Lessons from Emerging Markets. Columbia University.

Brennan, M.J., Subrahmanyam, A., 1996. Market microstructure and asset pricing: on the compensation for illiquidity in stock returns. Journal of Financial Economics 41, 441-464.

Brennan, M.J., Chordia, T., Subrahmanyam, A., 1998. Alternative factor specifications, security characteristics, and the cross-section of expected returns. Journal of Financial Economics 49, 345-373.

Brunnermeier, M., Pedersen, L.H., 2004a. Market liquidity and funding liquidity, Unpublished working paper, Princeton University.

Brunnermeier, M., Pedersen, L.H., 2004b. Predatory trading. Journal of Finance, forthcoming.

Chalmers, J.M., Kadlec, G.B., 1998. An empirical examination of the amortized spread. Journal of Financial Economics 48, 159-188.

Chordia, T., Roll, R., Subrahmanyam, A., 2000. Commonality in liquidity. Journal of Financial Economics 56, 3-28.

Chordia, T., Roll, R., Subrahmanyam, A., 2001a. Market liquidity and trading activity. Journal of Finance 56, 501-530.

Chordia, T., Subrahmanyam, A., Anshuman, V.R., 2001b. Trading activity and expected stock returns. Journal of Financial Economics 59, 3-32.

Cochrane, J.H., 2001. Asset Pricing. Princeton University Press, Princeton, NJ.

Constantinides, G.M., 1983. Capital market equilibrium with personal tax. Econometrica 51, 611-636.

Constantinides, G.M., 1986. Capital market equilibrium with transaction costs. Journal of Political Economy 94, 842-862.

Constantinides, G.M., Donaldson, J.B., Mehra, R., 2002. Junior can't borrow: a new perspective on the equity premium puzzle. Quarterly Journal of Economics 117, 269-296.

Datar, V.T., Naik, N.Y., Radcliffe, R., 1998. Liquidity and stock returns: an alternative test. Journal of Financial Markets 1, 203-219.

DeLong, J.B., Shleifer, A., Summers, L.H., Waldmann, R.J., 1990. Noise trader risk in financial markets. Journal of Political Economy 98, 703-738.

Dimson, E., Hanke, B., 2002. The expected illiquidity premium. Unpublished working paper, London Business School.

Duffie, D., Gârleanu, N., Pedersen, L.H., 2000. Over-the-counter markets. Econometrica, forthcoming.

Duffie, D., Gârleanu, N., Pedersen, L.H., 2002. Securities lending, shorting, and pricing. Journal of Financial Economics 66 (2,3), 307-339.

Duffie, D., Gârleanu, N., Pedersen, L.H., 2003. Valuation in over-the-counter markets. Unpublished working paper, Graduate School of Business, Stanford University.

Easley, D., Hvidkjær, S., O'Hara, M., 2002. Is information risk a determinant of asset returns? Journal of Finance 57, 2185-2221.

Eisfeldt, A.L., 2004. Endogenous liquidity in asset markets. Journal of Finance 59, 1-30.

Eleswarapu, V.R., 1997. Cost of transacting and expected returns in the Nasdaq market. Journal of Finance 52, 2113-2127. 
Eleswarapu, V.R., Reinganum, M.R., 1993. The seasonal behavior of liquidity premium in asset pricing. Journal of Financial Economics 34, 373-386.

Fama, E.F., French, K.R., 1992. The cross-section of expected stock returns. Journal of Finance 47, 427-465.

Fama, E.F., French, K.R., 1993. Common risk factors in the returns on stocks and bonds. Journal of Financial Economics 33, 3-56.

Fama, E.F., MacBeth, J.D., 1973. Risk, return, and equilibrium: Empirical tests. Journal of Political Economy 81, 607-636.

Friend, I., Blume, M., 1975. The demand for risky assets. American Economic Review 65, 900-922.

Gârleanu, N., Pedersen, L.H., 2004. Adverse selection and the required return. Review of Financial Studies 17 (3), 643-665.

Hansen, L.P., Richard, S.F., 1987. The role of conditioning information in deducing testable restrictions implied by dynamic asset pricing models. Econometrica 55, 587-614.

Harris, M., Raviv, A., 1993. Differences of opinion make a horse race. Review of Financial Studies 6, $473-506$.

Hasbrouck, J., 2002. Inferring trading costs from daily data: US equities from 1962 to 2001. Unpublished working paper, New York University.

Hasbrouck, J., Seppi, D.J., 2001. Common factors in prices, order flows and liquidity. Journal of Financial Economics 59, 383-411.

He, H., Wang, J., 1995. Differential information and dynamic behavior of stock trading volume. The Review of Financial Studies 8, 919-972.

Heaton, J., Lucas, D., 2000. Portfolio choice and asset prices: the importance of entrepreneurial risk. Journal of Finance 55, 1163-1198.

Holmstrom, B., Tirole, J., 2000. LAPM: a liquidity-based asset pricing model. Journal of Finance 56, $1837-1867$.

Huang, M., 2003. Liquidity shocks and equilibrium liquidity premia. Journal of Economic Theory 109, 104-129.

Huang, C., Litzenberger, R.H., 1988. Foundations for Financial Economics. Prentice-Hall, Englewood Cliffs, NJ.

Huberman, G., Halka, D., 1999. Systematic Liquidity. Columbia Business School.

Jones, C.M., 2001. A century of stock market liquidity and trading costs. Graduate School of Business, Columbia University.

Lintner, J., 1965. The valuation of risk assets and the selection of risky investments in stock portfolios and capital budgets. Review of Economics and Statistics 47, 13-37.

Ljungqvist, A., Richardson, M., 2003. The cash flow, return and risk characteristics of private equity. New York University.

Lustig, H., 2001. The market price of aggregate risk and the wealth distribution. Unpublished working paper, Stanford University.

Lynch, A.W., Tan, S., 2003. Explaining the magnitude of liquidity premia: the roles of return predictability, wealth shocks and state-dependent transaction costs. Unpublished working paper, New York University.

Markowitz, H., 1952. Portfolio selection. Journal of Finance 7, 77-91.

Markowitz, H., 2000. Mean-Variance Analysis in Portfolio Choice and Capital Markets. Frank J. Fabozzi Associates, New Hope, Pennsylvania.

Mossin, J., 1966. Equilibrium in a capital asset market. Econometrica 35, 768-783.

Newey, W., West, K., 1987. A simple, positive semi-definite, heteroskedasticity and autocorrelation consistent covariance matrix. Econometrica 55, 703-708.

Pastor, L., Stambaugh, R.F., 2003. Liquidity risk and expected stock returns. Journal of Political Economy 111, 642-685.

Persaud, A.D., 2003. Introduction. In: Persaud, A.D. (Ed.), Liquidity Black Holes. Risk.

Sadka, R., 2002. Momentum, liquidity risk, and limits to arbitrage. Unpublished working paper, Northwestern University.

Samuelson, P.A., 1958. An exact consumption-loan model of interest with or without the social contrivance of money. Journal of Political Economy 66, 467-482. 
Shanken, J., 1985. Multivariate tests of the zero-beta CAPM. Journal of Financial Economics 14, 327-348. Shanken, J., 1992. On the estimation of beta pricing models. Review of Financial Studies 5, 1-34.

Sharpe, W., 1964. Capital asset prices: a theory of capital market equilibrium under conditions of risk. Journal of Finance 19, 425-442.

Shumway, T., 1997. The delisting bias in CRSP data. Journal of Finance 52, 327-340.

Swan, P.L., 2002. Does "illiquidity" rather than "risk aversion" explain the equity premium puzzle? The value of endogenous market trading. Unpublished working paper, University of New South Wales.

Vayanos, D., 1998. Transaction costs and asset prices: a dynamic equilibrium model. Review of Financial Studies 11, 1-58.

Vayanos, D., Vila, J.-L., 1999. Equilibrium interest rate and liquidity premium with transaction costs. Economic Theory 13, 509-539.

Wang, A.W., 2002. Institutional equity flows, liquidity risk and asset pricing, Unpublished working paper, University of California, Los Angeles. 